\title{
ESSAY
}

\section{BRONTË, BLOOM, AND BORK: AN ESSAY ON THE MORAL EDUCATION OF JUDGES}

\author{
LINDA R. HirSHMAN $\dagger$
}

Allan Bloom's going to be very surprised when he finds out he attracted a feminist disciple. Actually, it isn't so much the content of his polemic against the moral relativism in American society ${ }^{1}$ that inspired this essay as it is the success of his book. ${ }^{2}$ Indeed, it isn't even so much its success as it is its timing-coming the same summer ${ }^{3}$ the nation confronted the appointment to the Supreme Court of Judge and Professor Robert Bork, a man by training ${ }^{4}$ and inclination ${ }^{5}$ the ultimate

† Associate Professor of Law, I.I.T. Chicago-Kent College of Law. A.B. 1966, Cornell University; J.D. 1969, University of Chicago. Once again, thanks to Randy Barnett and Dan Tarlock for conversation and for reading and rereading. This article was stimulated in large measure by discussions with Richard Posner about literature and with Gerald Gunther about the Constitution. It was presented at the Fourth Annual Workshop on Feminism and Legal Theory, University of Wisconsin, June 27, 1988; other proceedings of that conference will be published in 1 YALE J.L. \& FEMINISM (forthcoming in 1988). The research was supported by the Marshall Ewell Fund of the Chicago-Kent College of Law.

1 A. Bloom, The Glosing of the American Mind (1987).

2 The Closing of the American Mind was on The New York Times Best Seller list for forty-three weeks. See N.Y. Times, Apr. 3, 1988, $\S 7$ (Book Review), at 20. For ten weeks, from June 7 to August 9, 1987, it was number one. See N.Y. Times, Aug. 9, 1987, $\S 7$ (Book Review), at 30. Much of the significant content of the book echoes themes articulated years ago by Bloom's teacher, Leo Strauss. See Anastaplo, In re Allan Bloom: A Respectful Dissent, in Great Ideas Today 254-55 \& n.12 (1988). Compare A. Bloom, supra note 1 with L. Strauss, Liberalism, ANCIENT and Modern 1-64 (1968) and L. Strauss, NATURAL Right AND History 1-81 (1950) (German historicism and nihilism and the decline of political philosophy).

On July 1, 1987, President Reagan nominated Judge Bork to replace retiring Justice Lewis Powell. See Boyd, Bork Picked for High Court; Reagan Cites his 'Restraint'; Confirmation Fight Looms, N.Y. Times, July 2, 1987, at A1, col. 5. The Senate formally rejected Bork's nomination on October 23. See Greenhouse, Bork's Nomination is Rejected, 58-42; Reagan Stunned, N.Y. Times, Oct. 24, 1987, at A1, col. 3.

4 Judge Bork is a product of the University of Chicago and the University of Chicago Law School. He made his academic start as a Research Associate in the University of Chicago Law School Law and Economics Project. See 2 Almanac of THE Federal Judiciary 13 (B. Johnson, ed. 1988).

S See, e.g., Bork, The Impossibility of Finding Welfare Rights in the Constitution, 


\section{spokesman for American legal positivism. ${ }^{6}$}

During the summer of 1987, American society, or at least that part concerned with the life of the law, directly confronted the hollowness of value-free positivism in judging and its progenitor, morally neutral relativism in civic culture. ${ }^{7}$ Bloom's prescription for the wider culture is a return to the serious study of the humanities. ${ }^{8}$ The rejection of Bork the positivist and the burgeoning vitality of the law and literature movement ${ }^{\theta}$ (hence, the Brontë in the title of this essay) suggest a similar course for the law. This paper explores this conjunction.

The most influential manifestation of positivism in contemporary legal thought is its constitutional variant, interpretivism, ${ }^{10}$ which culminated in the extraordinary acclaim that greeted Professor Ely's Democracy and Distrust. ${ }^{11}$ In Part I, I describe the fall of constitu-

1979 WASH. U.L.Q. 695; Bork, Neutral Principles and Some First Amendment Problems, 47 IND. L.J. 1 (1971) [hereinafter Bork, Neutral Principles].

"Legal positivism is "law as it is," given its position by human authority, as distinguished from "law as it ought to be," derived from a normative criticism of law. See J. Murphy \& J. Coleman, The Philosophy of Law 22 (1984). Whether Judge Bork's positions were the only ones positivism might have produced is beyond the scope of this essay. For my purposes, it suffices to say that Bork is a leading exponent of a very important aspect of positivism that treats law as commands, and that the history of legal positivism is necessary to his position.

7 The use of the word "values" as a substitute for the language of right and wrong has so imbued legal discussion that I adopt the usage, albeit reluctantly, for purposes of describing past developments. Such a change in language has serious repercussions. See infra note 79 and accompanying text. Conscious of such seriousness, Bloom uses "values" only when he intends its debased, post-Nietzschean sense. See A. Bloom, supra note 1 , at 141-56, 194-216. When discussing the topic of Bloom's thought, rather than the parallel legal developments, I will follow his usage.

S See A. Bloom, supra note 1, at 62-67, 380-82.

- See, e.g., R. Weisberg, The Failure of the Word: The Protagonist as Lawyer in Modern Fiction (1984); J.B. White, Heracles' Bow: Essays on the Rhetoric and Poetics of the Law (1985); J.B. White, When Words Lose Their Meaning (1984) [hereinafter J.B. White, Words]; J.B. White, The Legal Imagination (1973); Ayer, The Very Idea of "Law and Literature," 85 Mich. L. REv. 895 (1987); Gerwitz, Aeschylus' Law, 101 HaRv. L. Rev. 1043 (1988); Posner, The Ethical Significance of Free Choice: A Reply to Professor West, 99 HaRv. L. Rev. 1431 (1986); West, Submission, Choice, and Ethics: A Rejoinder to Judge Posner, 99 HaRv. L. REv. 1449 (1986); West, Law, Rights, and Other Totemic Illusions: Legal Liberalism and Freud's Theory of the Rule of Law, 134 U. PA. L. REv. 817 (1986); West, Jurisprudence as Narrative: An Aesthetic Analysis of Modern Legal Theory, 60 N.Y.U. L. REv. 145 (1985).

${ }_{10}$ See infra note 24 (working definition of interpretivism).

$11 \mathrm{~J}$. Ely, Democracy and Distrust (1980). This seminal work won the prestigious Order of the Coif triennial book award in 1982 and inspired a flood of secondary literature. See, e.g., Ackerman, Beyond Carolene Products, 98 HARv. L. REv. 713 (1985); Dworkin, The Forum of Principle, 56 N.Y.U. L. REv. 469 (1981); Estreicher, Platonic Guardians of Democracy: John Hart Ely's Role for the Supreme Court in the Constitution's Open Texture, 56 N.Y.U. L. REv. 547 (1981); Lyons, Substance, Pro- 
tional interpretivism from those heights in light of Bloom's attack on moral relativism in the larger culture.

Part II considers the application of Bloom's solutions to law. Since the rejection of interpretivism recognizes that judging involves and will continue to involve judgments based on moral principles, how can society generally, and educators in particular, produce judges of the appropriate moral character and habits of mind to formulate such principles? The answer, I suggest, is implicit in the return of law to the humanities after its long and uneasy sojourn in the realm of science and is an answer that has been ripening along with the renewed interest in law and literature. Literature trains people in the reflection, consciousness, choice, and responsibility that make up the ability to engage in moral decisionmaking. It does so by presenting artificial, but concrete, universes in which premises may be worked out in conditions conducive to empathy but ambiguous enough to allow for the formation of moral judgment.

Having set forth the framework for the development of moral thought, I explore in Part III the legal status of abortion, the paradigmatic legal/moral question. The choice of the paradigm was easy, because the governance of abortion and the status of Roe $v$. Wade ${ }^{12}$ in American constitutional law has attracted more debate and discussion than any development since Brown $v$. Board of Education. ${ }^{13}$ Indeed, Roe may be the defining case for the next generation. ${ }^{14}$ Roe presents, in almost inextricable form, the knottiest moral and legal issues of per-

cess, and Outcome in Constitutional Theory, 72 CoRnell L. Rev. 745 (1987); Tribe, The Puzzling Persistence of Process-Based Constitutional Theories, 89 YALE L.J. 1063 (1980); Laycock, Taking Constitutions Seriously: A Theory of Judicial Review (Book Review), 59 TEx. L. REv. 343 (1981).

12410 U.S. 113 (1973).

13347 U.S. 483 (1954).

14 See Sunstein, Lochner's Legacy, 87 Colum. L. Rev. 873, 873 (1987). The centrality of the abortion issue to any discussion of law and morals approaches "sky is blue" obviousness. Even if not required as support for the proposition, however, the literature does include some interesting discussions of the moral/legal debate. See, e.g., Schneider, Moral Discourse and the Transformation of American Family Law, 83 Mich. L. REv. 1803, 1864 (1985) (Roe "was carefully considered," "exemplifies the trend toward diminished moral discourse," and "illustrates the fit between psychologic man and modern family law in general and between the psychologic view and substantive due process in particular."); see also Greenawalt, Religious Convictions and Lawmaking, 84 Mich. L. REv. 352, 371 (1985) ("Abortion is a tragic problem for our society. What some people sincerely regard as murder others see as the exercise of a fundamental human right. The level of mutual understanding is low. Many of those who favor abortion see the pernicious influence of religious views on the political process; others respond simplistically that abortion is a moral, not a religious, issue."); Rhoden, Trimesters and Technology: Revamping Roe v. Wade, 95 YALE L.J. 639, 669 (1986) ("Whether or not [the] dichotomy between late and early abortion is fully justified, it commands much scholarly respect, probably influenced the Roe Court, and is 
sonal autonomy, social morality and public authority. Any theory of the moral and legal development of judges must necessarily speak to this question.

My conclusion on the substantive matter is not novel: I believe the right to choose abortion is an issue not of privacy but of citizenship $^{15}$ - the least attractive, but critical, aspect of a multifaceted restructuring of society to abolish the disfiguring legacy of gender disadvantage. ${ }^{16}$ I seek to add to the existing discussion a study of selected fiction about women, and women and babies. ${ }^{17}$ In Part IV, I discuss my decision to select Charlotte Brontë's pathbreaking imagining of female autonomy, Jane Eyre, ${ }^{18}$ Nathaniel Hawthorne's The Scarlet Letter, ${ }^{19}$ and Margaret Atwood's The Handmaid's Tale, ${ }^{20}$ a picture of a society constructed to compel reproduction. ${ }^{21} \mathrm{I}$ argue in Part V that this body of literature can provide an understanding of the role of control over reproduction in female life, an understanding that should and could have supported the morality of Roe and that still can illuminate its application.

Finally, and most importantly, I conclude that literature's insights into the human condition merely illustrate the continuing role literature plays in a fully realized human and civic existence. As feminist criticism of literature has stood for meaning in a nihilist phase of literary scholarship, ${ }^{22}$ so, too, may it open the door to an enriched legal, thus

perhaps the closest this society has come to a consensus about the morality of abortion.").

${ }_{15}$ See Karst, The Supreme Court, 1976 Term-Foreword: Equal Citizenship

Under the Fourteenth Amendment, 91 HaRv. L. REv. 1, 32, 57-59 (1977).

16 See infra notes $178-84$ and accompanying text.

17 Or, as Elizabeth Hardwick characterizes it, a study of seduction and betrayal.

See E. Hardwick, Seduction and Betrayal: Women and Literature (1974).

18 C. Brontë, Jane Eyre (1847), reprinted in The Norton Anthology of Literature BY WOMEN 351 (S. Gilbert \& S. Guber eds. 1985).

19 N. Hawthorne, The Scarlet LetTer (1850), reprinted in Great Short Works of HawthorNe 43 (F. Crews ed. 1967).

${ }^{20} \mathrm{M}$. ATwood, The Handmaid's Tale (1985).

${ }^{21}$ I have been greatly assisted in writing this essay by the thriving decade-long project of feminist literary criticism. See N. AUERBACH, ROMANTIC IMPRISONMENT (1986); S. Gilbert \& S. Gubar, The Madwoman in the AtTic (1979); E. Showalter, A Literature of Their OWn (1977); see also Froula, So Many Female Rivals, N.Y. Times, Feb. 7, 1988, $\S 7$ (Book Review), at 12 (reviewing S. GiLBERT \& S. GUBER, THE WAR OF THE WORDS (1988) that chronicles misogynistic imagery in 20th century literature written by men); Gilbert \& Gubar, Sex Wars: Not the Fun Kind, N.Y. Times, Dec. 27, 1987, $\S 7$ (Book Review), at 1 (noting some thoughts on the war between the sexes in 20th century literature); Kolbert, Literary Feminism Comes of Age, N.Y. Times, Dec. 6, 1987, § 6 (Magazine), at 110 (exploring the rise of feminist criticism as a reaction to deconstructionism, noting it has become a major force in literary criticism, and predicting it will become more dominant as more women attain Ph.D.s).

${ }_{22}$ See Heilbrun, Bringing the Spirit Back to English Studies, in THE NEw FeMI- 
juridical, and ultimately public, life.

\section{The Short, Happy Life Of Value-Free CONSTITUTIONALISM}

\section{A. Legal Life}

Some say that Freud triumphed over his competitors in establishing his version of psychoanalysis in turn-of-the-century Vienna only because he was a better writer than they were. ${ }^{23}$ The same might be said for John Ely. Scholars have argued for an interpretivist approach to constitutional decisionmaking ${ }^{24}$ at least since Brown v. Board of Education. ${ }^{25}$ To cite only the most well-known example, in 1971, well before Ely wrote, then-Yale Professor Robert Bork explored the farreaching consequences of a strict adherence to only the most minimally debatable commands of the Constitution. ${ }^{26}$ But it's Ely whom everybody cites. ${ }^{27}$

Ely's thesis, grossly simplified, asserts that, if the text is ambigu-

NIST CRITICISM 21 (E. Showalter ed. 1985).

${ }^{23}$ See Polleck, Foreword to P. MAhony, Freud AS A Writer at x (2d ed. 1987)

("I am certain that Freud's literary appeal served to influence the spread of his ideas. His receiving the Geothe Prize for literature is evidence that some of his essays were masterpieces of writing, although certainly Freud's readers were influenced by the content of his works as well as by their style."); P. MAHONY, supra at 1.

24 See R. Berger, Government By JUdiciary 363-72 (1977) (arguing that adhering to an original intention interpretation of the Constitution is the only effective check on the judiciary); L. HAND, THE BILl of Rights (1958) ("No doubt it is inevitable ... that the personal proclivities of an interpreter will to some extent interject themselves into the meaning he imputes to a text, but in very much the greater part of a judge's duties he is charged with freeing himself as far as he can from all personal preferences ... ."); Monaghan, Our Perfect Constitution, 56 N.Y.U. L. REV. 353, 356 (1981) (opposing "any further extension of an approach that tests political outcomes for their consistency with some external, ideal pattern of distributive justice"); Rehnquist, The Notion of a Living Constitution, 54 TEx. L. Rev. 693, 698 (1976) (warning that once judges' authority is no longer tied to the language of the Constitution, their role necessarily changes to one of "a small group of fortunately situated people with a roving commission to second-guess Congress [and] state legislatures . . . concerning what is best for the country"). Although interpretivism may be divided into schools of relative rigor, the premises for our purposes are that " $t \mathrm{t}]$ he whole aim of construction, as applied to a provision of the Constitution, is . . to ascertain and give effect to the intent, of its framers and the people who adopted it." "Home Bldg. \& Loan Ass'n v. Blaisdell, 290 U.S. 398, 453 (1934) (Sutherland, J., dissenting).

25347 U.S. 483 (1954). Arguably, the debate has raged at least since Fletcher v. Peck, 10 U.S. (6 Granch) 87 (1810). See Sunstein, supra note 14, at 874 n.9. As Professor Sunstein notes, however, each generation has its "defining" case that sets the tone of its debate, and Brown was certainly one of ours. See id. at 873 .

${ }^{28}$ See Bork, Neutral Principles, supra note 5, at 10-12.

27 A computer search of forty major law reviews in the LEXIS ALLREV file on September 23, 1988, found that Ely's book was cited in 542 documents. Bork's article was cited in only 185 . 
ous, judges cannot ground their efforts to interpret the Constitution on matters of substance in any coherent source. ${ }^{28}$ Left with the choice, in the exercise of judicial review, between the "judge's own values," and the values of the legislature, Ely chooses the legislature's. ${ }^{29}$ Thus far, his argument seems similar to Bork's. ${ }^{30}$ Ely's position diverges from Bork's, however, in that he does not abandon the inquiry. Instead, in search of "the evident spirit of certain of the provisions,"31 he articulates a theory of constitutional interpretation based on two overriding commitments - to fair procedures and access to participation. ${ }^{32}$ When the constitutional text is imperfectly informative, Ely asserts, these process-based goals guide judges in the interpretive task. ${ }^{33}$

Ely's process-based theory derived much of its appeal from its capacity to sound tough-minded on "values" without turning the clock back on the constitutional developments of the previous twenty five years. ${ }^{34}$ This was easier for him than for scholars like Bork who have a longer history of interpretivism, because it was Roe that prompted Ely's conversion..$^{36}$ Roe, which Ely characterized as both "controversial" and "the clearest example of noninterpretivist 'reasoning' on the part of the Court in four decades," forced Ely to "think about which camp [he fell] into" and thereafter to subordinate politics to the interest of proper legal philosophy. ${ }^{37}$ Predictably, however, the ensuing debate focused on Ely's prescription for change in constitutional theory, rather than his

${ }^{28}$ See J. ELY, supra note 11 , at $43-44$.

29 Id. at $44,72$.

${ }^{30}$ Compare id. at 102 (recognizing "the unacceptability of the claim that . . . judges are better reflectors of conventional values than elected representatives") with Bork, Neutral Principles, supra note 5, at 10-11 ("Courts must accept any value choice the legislature makes unless it clearly runs contrary to a choice made in the framing of the Constitution.").

31 J. ELY, supra note 11 , at 73.

32 See id. at 87, 102-03.

ss See id. at 73-104.

34 The litmus tests are, of course, Griswold v. Connecticut, 381 U.S. 479 (1965), and Skinner v. Oklahoma, 316 U.S. 535 (1942), which the Senate used so effectively against Judge Bork. See S. Exec. ReP. No. 7, 100th Cong., 1st Sess. 30 (1987) [hereinafter SENATE REPORT]. Ely is less than forthcoming on Griswold. See J. Ely, supra note 11 , at 219 n.118, 221 n.4. However, since he cites his treatment of Griswold in his earlier attack on Roe, see Ely, The Wages of Crying Wolf, 82 YALE L.J. 920, 928 (1973), one presumes he intends to reiterate his earlier position. In Wages, Ely defends Griswold as adequately related to fourth amendment concerns about enforcing the prohibition on contraceptive use. See id. at 930 . Although he decries the fundamental rights analysis in Skinner, he would reconsider the sterilization law as inadequately rational under the fourteenth amendment or "strongly argue" for its classification as a cruel and unusual punishment. See J. ELY, supra note 11, 245-46 n.38.

35 See J. ELY, supra note 11, at 2-3 (Roe forced constitutional scholars "to think about which camp" they supported regarding interpretivism.).

${ }^{36}$ Id. at 2.

s7 Id. at 2-3, 71-72. 
theories for ratification of past decisions. ${ }^{38}$ Thus, his advice became essentially indistinguishable from that of the other interpretivists.

In any case, after the publication of Democracy and Distrust, one line seemed clearly drawn. If the Court does not base decisions such as Roe v. Wade ${ }^{39}$ in some textual authority more convincing than the Court used in the opinion, one can defend such decisions only on the grounds that judges may occasionally impose their personal values of substance in the admittedly undemocratic exercise of judicial review. Two responses were possible, and each has been tried. One might either attempt to duck the battle by more securely locating decisions in, for instance, the language of the equal protection clause, ${ }^{40}$ or one could bite the bullet and defend the judge's role as occasional moral arbiter. ${ }^{41}$

By the time the issue surfaced in the public eye with the proposed

${ }^{38}$ See Nichol, Giving Substance its Due (Book Review), 93 YALE L.J. 171, 171 (1983) (reviewing P. Babbitt, Constitutional Fate (1982) and M. Perry, The Constitution, THE CourTs, AND HUMAN Rights (1982)) (characterizing Ely's book as the "opening shot in another battle between proponents of activism and restraint, rather than the final volley").

39 410 U.S. 113 (1973).

10 See Regan, Rewriting Roe v. Wade, 77 Mich. L. Rev. 1569, 1569 (1979) (forbidding abortions requires women to be "Good Samaritans" in violation of the equal protection clause); cf. Karst, supra note 15, at 57-59 (Roe can be seen as a "woman's role" case, implicating the principle of equal citizenship); Tribe, The Abortion Funding Conundrum: Inalienable Rights, Affirmative Duties, and the Dilemma of Dependence, 99 HARV. L. REv. 330, 335-36 (1985) (The right to abortion is collective rather than individual, is inalienable, and should impose affirmative duties on government.).

11 See Dworkin, The Forum of Principle, 56 N.Y.U. L. REv. 469, 470-71 (1981) (contending that it is impossible for judges to decide constitutional questions without making substantive political decisions); Grey, The Constitution as Scripture, 37 STAN. L. REv. 1, 18-24 (1984) (advancing historical and practical justifications for extratextual judicial review); Grey, Do We Have an Unwritten Constitution?, 27 SraN. L. REv. 703, 717 (1975) [hereinafter Grey, Unwritten Constitution] (arguing that equal protection decisions are the modern offspring of "the natural rights tradition that is so deeply embedded in our constitutional origins"); Perry, Abortion, the Public Morals, and the Police Power: The Ethical Function of Substantive Due Process, 23 UCLA L. REv. 689, 735 (1976) (limiting state police power to the pursuit of the "public welfare" requires the Court to "ascertain the contents of social conventions"). One rather unexpected consequence of linking Roe to Lochner v. New York, 198 U.S. 45 (1905), see, e.g., Ely, supra note 34, at 937-43, has been a mini-revival of Lochner. See B. Siegan, Economic Liberties and THE Constitution 318 (1980) (proposing change in "Supreme Court policy that rejects judicial review of governmental restraints on economic activity"); see also Posner, Law and Literature: A Relation Reargued, 72 VA. L. REV. 1351, 1383-84 \& n.99 (1986) (noting a "growing scholarly movement" that regards Lochner as "correctly decided"); Sunstein, supra note 14, at 875 (If Lochner is viewed as imposing a "constitutional requirement of neutrality" with respect to the existing distribution of wealth then it "hardly has been overruled."). Professor Bernard Siegan, the most vocal proponent of the revival, was nominated to the Ninth Circuit Court of Appeals; interestingly, his nomination was as unsuccessful as Judge Bork's. See Withdrawals, 57 U.S.L.W. 2180, 2180 (Sept. 27, 1988) (Professor Siegan's nomination withdrawn). 
appointment of Robert Bork to the Supreme Court, scholars and judges following the latter course had suggested three responses to interpretivism: prophetic, professional, and philosophical. The advocates of the prophetic, or religious, school ${ }^{\mathbf{2}}$ were refreshingly frank. The United States had, they said, a tradition of seeking moral answers to constitutional questions, whether those answers derive from an evolving visionary process ${ }^{43}$ or from an ongoing substratum of natural rights philosophy. ${ }^{44}$ Although the country might, and did for some periods, opt for the more positivist tradition of interpretivism, the Court's role to lead the society in the direction of the city on the hill ${ }^{45}$ is equally legitimate and grounded in history, text, and practicality.

The second, or professional, response saw a particular responsibility and authority in the legal profession generally and judges in particular. ${ }^{46}$ Professor Sunstein, for example, articulated a self-confessed role for judges as moderating the democratizing tendencies in American society with the greater insularity and opportunity for reflection that the profession has historically enjoyed, and that, at least for federal judges, Article III ensures. ${ }^{47}$ Judges' subjectivity in performing noninterpretivist review, the professional school asserts, is constrained by their training, their discomfort with misusing or abusing precedent, and the evolution of thinking about social problems that various institutions of the profession provide. ${ }^{48}$ Unfortunately, each of the first two noninterpretivist positions stops short of fully articulating the moral, social, and political guideposts that would direct the judges in performing the tasks

12 See M. PERRY, supra note 38, at 100-01; Fiss, Objectivity and Interpretation, 34 Stan. L. Rev. 739, 753 (1982); Greenawalt, supra note 14, at 357; Perry, The Authority of Text, Tradition, and Reason: A Theory of Constitutional "Interpretation," 58 S. CAL. L. REv. 551, 557-63 (1985); see also Levinson, "The Constitution" in American Civil Religion, 1979 SuP. CT. REv. 123, 132-36 (describing debate between interpretivists and noninterpretivists as one between Catholic and Protestant ethics).

43 See M. Perry, supra note 38, at 100-01; Perry, supra note 42, at 564.

44 See Grey, Unwritten Constitution, supra note 41, at 715-17.

45 See Winthrop, A Model of Christian Charity (1630), reprinted in 2 WINTHROP PAPERS 282, 295 (1931).

16 See, e.g., Sunstein, Interest Groups in American Public Law, 38 STaN. L. REV. 29, 86 (1985) (envisioning a "special role for courts" in protecting constitutional rights of citizens from "factional power over lawmaking processes").

${ }^{47}$ See id. at 49-59, 86; see also Fitts, The Vices of Virtue: A Political Party Perspective on Civic Virtue Reforms of the Legislative Process, 136 U. PA. L. REv. 1567, 1574 (1988) ("[L]egal academics have expressed renewed interest in improving the performance of legislative decisionmaking through judicial review.").

48 See Barnett, Foreword: Judicial Conservatism v. A Principled Judicial Activism, 10 HaRv. J.L. \& PUB. POL'y 273, 282-86 (1987) ("tradition" and "reason" guide and constrain judges); Fiss, supra note 42 , at 757-58 (judicial review is bounded by the requirements of the legal community). 
the scholars spend so much prose assigning to them. ${ }^{19}$

By contrast, the third group, the philosophers, ${ }^{50}$ did not balk at providing substantive answers. Like philosophers of the past, each attempts to construct a world view that will provide answers to the hard substantive questions the society asks its judges to decide. Thus, for example, John Rawls reaches to a Utopian vision to reconstruct the original understandings on which a just society must be based..$^{\mathbf{1 1}}$ From these understandings would flow answers; answers being available, noninterpretivism would involve not the judges' individual or timebound "values," but, rather, the application of ascertainable universal truths. As interpretivists like Ely have been quick to point out, however, these sources of wisdom conflict. ${ }^{62}$ Other commentators criticize political philosophy as too abstract to answer real social questions. ${ }^{53}$ Ronald Dworkin comes closest to attaining a middle ground between the philosophers and the professionals. While acknowledging the usefulness of philosophic insight, he suggests that a judge's forays beyond the text are liberated and constrained by the necessity of achieving coherence-the belief that the outcome should fit in the broader legal picture society has painted in answering other questions. ${ }^{54}$

All this was in the air when Ronald Reagan nominated Robert Bork to fill Lewis Powell's seat on the Court. The debate that ensued contains many lessons. That the debate occurred at all is, of course, in some sense fortuitous; if Lewis Powell hadn't occupied a critical centrist position on a sharply divided court (or for that matter if Oliver North had been a better shredder), the outcome might have been different. But much public life involves such concatenations. Fortuitous or not, Bork's appointment presented the country with the opportunity to consider the interpretivist position that noninterpretivism is constitu-

19 See, e.g., Lyons, supra note 11, at 763 ("[N]either do I believe it has been shown, or that we can assume, that the approach to interpretation I have advocated yields interpretations that are truer to the Constitution than the alternatives."); Sunstein, supra note 14, at 918 ("[T]he task for the future is to develop theories of distributive justice, derived from constitutional text and purposes, that might serve as the basis for evaluating any particular practice.").

so See R. Nozick, Anarchy, State, and Utopia (1974); J. Rawls, A TheORY OF JUSTICE (1971).

SI See J. RAwls, supra note 50, at 13.

${ }^{2}$ See J. ELY, supra note 11, at 58 ("There simply does not exist $a$ method of moral philosophy.").

${ }^{63}$ See, e.g., Ayer, supra note 9, at 911-12 (" 'Mainstream' jurisprudence may be rich in abstract systemization, but it offers very little on the notion of what it means for a person to be good." (footnote omitted)); Wonnell, Problems in the Application of Political Philosophy to Law, 86 Mich. L. Rev. 123, 124 (1987) ("Some political philosophies that may be unobjectionable as pure normative systems are nevertheless likely to produce systematically objectionable results when they are concretely applied.").

s4 See R. Dworkin, Law's EMPIre 87-88 (1986). 
tionally illegitimate in a representative democracy as well as politically unwise for the court as an institution. The public hearings did not approach the analytic depth of the decades-long academic argument. However, the debate over Bork's nomination is perhaps more compelling than the arid scholarly disputes, because, like works of literature, it involved specific people, specific issues, and a specific resolution.

During his confirmation hearings, and in his writings, Bork made two relatively forthright arguments. First, he supported the parsimony of the constitutional protections for individual liberties, particularly a person's control over various sexual decisions the Court has loosely grouped under the rubric "privacy." feelings about the desirability of the political branches interfering in these decisions, Bork contended that, absent textual guidance, a judge neither could nor should impose his ideas of proper conduct on the popular branches of government. ${ }^{\text {s6 }}$

If Bork and the interpretivists were correct about the judges' proper roles, the popularly elected Senate should have welcomed the chance to rein in its overreaching fellow branch and reverse the decisions imposed upon popularly elected legislatures in the interests of the judges' personal "values." But that's not what happened. ${ }^{57}$ In any public event such as the rejection of a Supreme Court nominee, many forces coalesce, but one lesson may be drawn from all the debate over Bork's nomination. In the years since Skinner $v$. Oklahoma ${ }^{\mathbf{5 8}}$ the Court has prevailed on its authority to articulate some public values of substance beyond the strict language of the constitutional text. ${ }^{59}$ If Judge Bork was going to tell the country that that authority did not exist in the Constitution (and on the occasion of its Bicentennial, to

s5 See, e.g., Supreme Court Nominee's Record Examined: Bork Faces Tough Questions on Privacy and Equal Rights, 45 CoNG. Q. 2258, 2267 (1987) (Judge Bork responded to Sen. Heflin's questions by noting that "I have heard fairly strong moral arguments for abortion, . . . [but] I have not heard anybody yet root it in the Constitution.").

sB See id. at 2259 ("[W]here the Constitution does not speak ... then a judge may not say, I place a higher value upon a marital relationship than I do upon an economic freedom. ... [I]f there is nothing in the Constitution, the judge is enforcing his own moral values, which I have objected to."); $c f$. SENATE REPORT, supra note 34, at 8 (Senate Judiciary Committee majority report rebutting Bork's denial of rights beyond those specifically enumerated in the Constitution).

${ }_{37}$ Senate RePort, supra note 34, at 8 (Senate Judiciary Committee report recommending that Judge Bork not be appointed to the Supreme Court, and approving judicial enforcement of unenumerated rights). The Senate rejected Judge Bork's nomination 58-42. See 133 CoNG. REC. S15011 (daily ed. Oct. 23, 1987).

s8 316 U.S. 535 (1942) (seminal privacy case declaring an Oklahoma recidivist sterilization law violated the equal protection clause).

${ }^{89}$ See R. BERGER, supra note 24, at 283-99 (discussing Warren Court's approval of rights not enumerated in the Constitution). 
boot), the country didn't want to hear it. ${ }^{60}$ This lesson is important for the prudential and democratic pillars of interpretivism, but it's still the minor lesson. ${ }^{61}$

The larger lesson was less obvious on the face of the Bork debate but, upon reflection, was clearly there. Throughout the hearings, Bork consistently reiterated the interpretivist position that he should separate his judgment that the government was behaving in a profoundly wrongful way from a judicial decision that it should be stopped. ${ }^{62}$ His listeners just weren't buying.

It's really not Bork's fault, and his surprise and dismay at his failure to sell his position is understandable. Value-neutral judging fits comfortably with the moral relativism that seems to have dominated American civic culture since the end of the Vietnam War era. ${ }^{63} \mathrm{He}$ had good precedent for his relativism in the century-long effort to treat law as a science, rather than a human construct, culminating in the retreat from judicial value formation that dominated American constitutional discourse from the "switch in time that saved nine" in 1937 until the 1954 decision in Brown. He had immediate scholarly support in interpretivism, which the academy had kept alive throughout the era of the Warren Court, culminating in the extremely favorable reception of $D e$ mocracy and Distrust. If all these forces supported his candidacy, however, his defeat is also in some measure their rejection.

${ }^{60}$ Or at least the Senate did not want to hear it. See supra notes $56 \& 57$.

61 A victory for judicial value-formation in the court of public opinion, of course, does not necessarily represent ultimate virtue. Moreover, such victories are hardly eternal; witness the unhappy fate of Dred Scott v. Sandford, 60 U.S. (19 How.) 393 (1857). See Rehnquist, supra note 24, at 702 ("The Dred Scott decision . . . was repealed . . . in law by the Civil War amendments."). The lesson I draw from Dred Scott, however, is that the answer to judicial mistakes is not judicial withdrawal but better decisions. See infra notes 312-14 and accompanying text. Nonetheless, assuming the Court's key decisions in modern times have been, on the whole, correct ones, the Bork debates exemplify the Court's success in performing the function of moral leadership the interpretivists say it cannot fulfill.

62 See Senate RePort, supra note 34 , at 9 (" $[\AA]$ judge's authority derives entirely from the fact that he is applying the law and not his own personal values." (quoting Judge Bork)).

63 See A. Broom, supra note 1, at 25-43 (discussing the acceptance of relativism); infra notes 69-90 and accompanying text. Bloom actually dates the era to the beginning of the 1960s with the rejection of traditional immigrant upbringing and the opening up of education, formerly available only to those in or aspiring to the values of the American ruling class, to minorities, women, and other indigestible sorts. See id. at 313-35. I tend to agree with Professor Fiss that, on the contrary, the 60s were a time of widespread moral involvement. See Fiss, supra note 42, at 741 (describing today's nihilism as a reaction to the moralism of the $60 \mathrm{~s}$ ). 


\section{B. Social Life}

Bork might have been somewhat less taken aback, if he had stopped to consider the popularity of The Closing of the American Mind $^{84}$ during his confirmation hearings. ${ }^{65}$ Bloom's book does not purport to be a book about the law. Written by a teacher of philosophy at the University of Chicago, ${ }^{68}$ it is, if anything, an essay on the life of the mind in American democratic society. ${ }^{67}$ Although Bloom's effort may seem remote from the Senate Judiciary Committee, his expression of dismay at the moral relativism in American culture pointed directly to the rejection of value neutrality in judging. If constitutional interpretivism rests on the critical assumption of moral relativism as philosophical principle, ${ }^{68}$ this immensely successful attack on its foundation warrants further study.

\section{The Problem of the Relativity of Truth}

Bloom acknowledges at the outset that his concerns arose largely as a response to the students who have come across his path during his thirty years of teaching. ${ }^{68}$ Describing them, Bloom makes the first of the points that bear on our inquiry:

The relativity of truth [to them] is not a theoretical insight but a moral postulate, the condition of a free society, or so they see it. They have all been equipped with this framework early on, and it is the modern replacement for the inalienable natural rights that used to be the traditional American grounds for a free society. ${ }^{70}$

\footnotetext{
${ }^{64}$ See supra note 2.
}

65 Which just goes to show that the Court may not "follow the New York Review of Books," J. ELY, supra note 11, at 58 (mocking Ronald Dworkin's suggestion that judges may draw some enlightenment from society's ongoing philosophical debate), but nominees, at least, probably shouldn't ignore it. Not that the New York Review of Books was all that impressed with Bloom. See Nussbaum, Undemocratic Vistas, N.Y. REv. Books, Nov. 5, 1987, at 20, 23 ("[Bloom's] argument contains extraordinary gaps and errors . . . ."). Disagreeable as the reviewer found many of Bloom's ideas, however, she saw Closing as provoking a "discussion of democratic education." Id. at 26; see also infra notes 143-47 and accompanying text (discussing my disagreements with Bloom).

Be Bloom's title is Professor, Committee on Social Thought and the College; he is also Co-director of the John M. Olin Center for Inquiry into the Theory and Practice of Democracy.

${ }^{67}$ Bellow, Foreword to A. Bloom, supra note 1, at 18.

${ }^{88}$ See supra note 63 and accompanying text.

69 See A. Bloom, supra note 1 , at 21 .

${ }^{70} \mathrm{Id}$. at 25. 
In coming to this relativism, Bloom contends, students have lost touch with the "unity, grandeur and attendant folklore of the founding heritage" tanceship with which is necessary if the "mind's eye" is to "see the delicate distinctions among men, among their deeds and their motives."73 Liberated by relativism from the prospect of seeking, finding, and leading a morally elevated existence, the mass of Bloom's students lead lives of loud dissipation. Absorbed in meaningless and ultimately arid gratification of the senses, they are unacquainted with classic texts, ${ }^{74}$ addicted to orgasmic and puerile music, ${ }^{75}$ and engaged in "[r]elationships [that are] gray, amorphous, suggestive of a project, without a given content, and tentative." Although his dismay at the state of university life obviously inspired Bloom's essay, he ultimately addresses the larger question: how did relativism come to dominate the American psyche and intellect? He applies to this problem his longheld ${ }^{77}$ assumption that philosophy matters in human affairs as he looks for an answer to the recent history of philosophy in American society. ${ }^{78}$ Bloom seeks insight by examining changes in language. ${ }^{79} \mathrm{He}$ finds an

${ }^{71}$ Id. at 55. Bloom attributes this disillusionment to Becker's historicism, Dewey's pragmatism, and Beard's Marxism. See id. at 55-56. A similar argument may be made about the effect of these philosophies on the development of American legal positivism. Accordingly, one simply may not discard as coincidental the simultaneous appearance of a revival of moral self-confidence in jurisprudence and a revival of a sense of the "grandeur" and "folklore" of the founding. The notion that non-interpretivist jurisprudence must rest on such a mythos is generally attributed to Max Lerner. See Lerner, Constitution and Court as Symbols, 46 YALE L.J. 1290, 1291-95 (1937) (commenting that the psychological foundations of carte blanche Supreme Court authority derive from the role of the constitution and courts as civil-religious symbols). Its modern revival is usually credited to Sanford Levinson. See Levinson, supra note 42, at 124-25 (comparing constitutional law to the interpretation of religious documents); see also $\mathrm{M}$. PERRY, supra note 38, at 97-100 (describing the "religious" role of the Court); Burt, Constitutional Law and the Teaching of the Parables, 93 YALE L.J. 455, 486-89 (1984) (arguing that courts interpreting the Constitution sometimes have a duty to lead a majority towards understanding its community of interest with the minority).

${ }_{72}$ See A. Bloom, supra note 1 , at 61 . In a particularly striking insight in this era of moral relativism, Bloom attributes the loss to his students' separation from the Bible, once the unquestioned center of life to their religious parents or grandparents, because the Bible, taken seriously, was at least one book of substance in everyone's life. See id. at $58-60$.

${ }^{73}$ Id. at 61 .

74 See id. at 58-61.

${ }^{75}$ See id. at 78-81.

76 Id. at 124.

77 See, e.g., A. Bloom, Shakespeare's Politics 1-2, 11-12 (1964).

78 See A. Bloom, supra note 1, at 38-39.

70 In this, he sounds a lot like James Boyd White: "An alteration in language ... is not merely a lexical event, and it is not reversible by insistence upon a set of proper definitions. It is a change in the world and the self, in manners and conduct and sentiment." J.B. WHITE, WoRDS, supra note 9, at 4. 
answer in the substitution of the word "values" for the language of good and evil, ${ }^{80}$ a result he attributes to the introduction of poisonous doses of German nihilism into American culture and education. ${ }^{81}$

Inquiring into the philosophical underpinnings of American society, Bloom first reminds us that the American founding draws primarily on the Enlightenment tradition:

Americans are Lockeans: recognizing that work is necessary (no longing for a nonexistent Eden), and will produce wellbeing; following their natural inclinations moderately, not because they possess the virtue of moderation but because their passions are balanced and they recognize the reasonableness of that; respecting the rights of others so that theirs will be respected; obeying the law because they made it in their own interest. ... [A]s Leo Strauss put it [describing Locke], the moderns "built on low but solid ground."82

Bloom also reminds us that the alternative tradition of Rousseau, linking man to nature and turning its back on Locke, ${ }^{83}$ forms a significant and contradictory undercurrent in American tradition. ${ }^{84}$ Bloom concludes that these strands of intellectual heritage, while inconsistent at one level, share the common reverence for the philosophical inquiry and for the possibility of following a moral path. ${ }^{85}$

Into this philosophic mix, according to Bloom, came the refugees from Hitler in the 1930 s, bringing with them the Nietzschean tradition and its latter-day incarnations in Heidegger, Weber, and Freud. ${ }^{\mathbf{8 6}}$ Bloom summarizes the core of Nietzsche's thought:

"God is dead." Good and evil now for the first time appeared as values, of which there have been a thousand and one, none rationally or objectively preferable to any other. . . . In short, Nietzsche with the utmost gravity told modern man that he was free-falling in the abyss of nihilism. Perhaps after having lived through this terrible experience,

${ }^{80}$ See A. Bloom, supra note 1, at 141-43, 238.

81 See id. at 141-56.

82 Id. at 167; see id. at 163-67. Leo Strauss, philosopher and Professor of Philosophy at the University of Chicago during Bloom's undergraduate days, was the founder of a school of political philosophy, Straussianism, that promotes liberal education, particularly the study of the "Great Books." See Mansfield, Democracy and the Great Books, New Republic, Apr. 4, 1988, at 33, 33-37; Rorty, That Old-Time Philosophy, New Republic, Apr. 4, 1988, at 28, 28-33.

Sa See A. Bloom, supra note 1 , at 169 .

See id. at 171-72.

${ }^{85}$ See id. at 162-63.

${ }^{86}$ See id. at 148-51. 
drunk it to the dregs, people might hope for a fresh era of value creation, the emergence of new gods.

Modern democracy was, of course, the target of Nietzsche's criticism. Its rationalism and its egalitarianism are the contrary of creativity. . . . Nietzsche's call to revolt against liberal democracy is more powerful and more radical than is Marx's. ${ }^{87}$

One would have thought that German nihilism would be both profoundly dangerous and inimical to the American society described above. Instead, something quite remarkable happened:

[T] he latest models of modern democratic or egalitarian man find much that is attractive in Nietzsche's understanding of things ....

[T] The democratic man requires flattery, like any ruler, and the earliest versions of democratic theory did not provide it. They justified democracy as the regime in which very ordinary people were protected in their attempt to achieve very ordinary and common goals. It was also the regime dominated by public opinion, where the common denominator set the rule for everyone. Democracy presented itself as decent mediocrity as over against the splendid corruption of older regimes. But it is quite another thing to have a regime in which all the citizens can be thought to be at least potentially autonomous, creating values for themselves. A value-creating man is a plausible substitute for a good man, and some such substitute becomes practically inevitable in pop relativism, since very few persons can think of themselves as just nothing. ${ }^{88}$

In adapting Nietzsche's vision to America-and this may explain why it was addictive rather than inimical-American education simply stripped it of its darkness and extremism: "on enchanted American ground the tragic sense has little place, and the early proponents of the new social science gaily accepted the value insight, sure that their values were just fine, and went ahead with science."8s

Bloom pens a harsh indictment of the effect of this unexpected flood of Teutonic thought. Listing each of the words in the value-relative vocabulary ("life-style," "values," "ideology," "charisma"), he de- 
scribes their fatal charm:

These words are there where thoughts should be, and their disappearance would reveal the void. . . . They appear to justify one's tastes and deeds, and human beings need to have such justification, no matter what they may say. . . .

However, these words are not reasons, nor were they intended to be reasons. All to the contrary, they were meant to show that our deep human need to know what we are doing and to be good cannot be satisfied. ${ }^{90}$

Though unintended, this passage throws a blinding light on the weakness of interpretivist thought. In the critical opening chapters of Democracy and Distrust, Ely addresses-as he must-the prospect that judges can make decisions on matters of substance based on what is good or bad for the life of American society. ${ }^{91}$ Rejecting, one by one, the possibility of grounding such decisions in natural law, reason, consensus, and history, Ely repeatedly asserts the relativity of truth..$^{92}$ Thus, on natural law, he states: "in fact the list of causes natural law has supported is almost infinite." issues is not the same as discovering absolute ethical truth." ${ }^{44}$ On consensus: "one can convince oneself that some invocable consensus supports almost any position a civilized person might want to see supported." On tradition: "Whose traditions count? America's only? Why not the entire world's?" An An his most disingenuous tone: "For some reason Justice Frankfurter liked to refer to the "traditions of the English-speaking people."

Having assumed away all the sources from which American men

80 Id. at 238 .

91 See J. ElY, supra note 11 , at 43-72.

${ }_{92}$ See $i d$. at 54 ("[O]ur society rightly does not[] accept the notion of a discoverable and objectively valid set of moral principles. ...").

93 Id. at 51 .

24 Id. at 54 .

$95 \mathrm{Id}$. at 67.

${ }^{96} \mathrm{Id}$. at 60 .

${ }^{97}$ Id. (citing Wolf v. California, 338 U.S. 25, 28 (1949) (Frankfurter, J., concurring). While Justice Frankfurter never used that exact phrase, Ely is quite right that he frequently employed the concept. See, e.g., Francis v. Resweber, 329 U.S. 459, 467 (1947) (Frankfurter, J., concurring) (writing about "the struggle for freedom of English-speaking peoples"); Adamson v. California, 332 U.S. 46, 67 (1947) (Frankfurter, $\mathrm{J}$, concurring) ("Judicial review ... imposes upon this Court an exercise . . . to ascertain whether [the proceedings] offend those canons of decency which express the notions of justice of English-speaking peoples . . . .”); Bridges v. California, 314 U.S. 252, 284 (1941) (Frankfurter, J., dissenting) (speaking of "liberty-loving Englishspeaking peoples").

Justice Frankfurter's language is more difficult to dismiss if one restores it to its 
and women for two hundred years "[knew] what we are doing and to be good," Ely triumphantly plays what he considers the trump card. All that is left is the judges' own "values." on his assumption of the absolute truth of the relativity of truth. Bork's rejection-however inchoate its expression-was its rejection.

\section{Solutions}

\section{a. Article III}

Bloom teaches undergraduates and writes an essay titularly addressed to the subject of undergraduate education. He has much less to say about the central subject of this paper-the role of the life-tenured judiciary in the formation and enforcement of moral values in a democratic society. ${ }^{100}$ But judges, especially life-tenured judges, have their counterparts in Bloom's universe:

[I]n egalitarian society practically nobody has a really grand opinion of himself, or has been nurtured in a sense of special right and a proud contempt for the merely necessary. Aristotle's great-souled man, who loves beautiful and useless things, is not a democratic type. Such a man loves honor but despises it because he knows he deserves better .... He can take for granted the things that are the ends of most men's strivings - money and status. He is free, and must look for other fulfillments .... All of this is salutary for the intellectual life, and none of it is endemic to democracy. ${ }^{101}$

In another passage, decrying the loss of individualism in an egalitarian society, Bloom describes the quintessential political gentleman,

historical context. Frankfurter's sentence reads in full:

The knock at the door, whether by day or by night, as a prelude to a search, without authority of law but solely on the authority of the police, did not need the commentary of recent history to be condemned as inconsistent with the conception of human rights enshrined in the history and constitutional documents of English-speaking peoples.

Wolf, 338 U.S. at 28. As Professor Hegland observed, perhaps the 1940s were not the best time to abandon the traditions of the English-speaking peoples. Cf. Hegland, Goodbye to Deconstruction, 58 S. CAL. L. Rev. 1203, 1220 (1985) ("We live in a century that has produced Hitler and Stalin. Perhaps now is not the time to dump the Rule of Law.").

${ }^{88}$ Cf. A. Bloom, supra note 1 , at 238.

s9 J. ELY, supra note 11 , at 72 .

100 Indeed, Bloom takes the Socratic lesson seriously and includes a lengthy caution against the philosopher becoming too closely engaged in the affairs of public life.

See A. BLoom, supra note 1 , at 243-312.

101 Id. at 250-51. 
Winston Churchill,

inspired by his ancestor Marlborough . . . [who] said that Shakespeare was essential to his education. And Shakespeare learned a large part of what he knew about statesmanship from Plutarch. This is the intellectual genealogy of modern heroes. The democratic revolution of the mind extinguishes such old family lines and replaces them with decision-making theory, in which there is no category for statesmanship, let alone heroes. ${ }^{102}$

Moreover, when Bloom expands his analysis beyond the intellectual poverty of our educational system, he most often concentrates on the civil rights movement-the event for which the federal courts, more than any other institution in the society, are responsible. ${ }^{103}$ Bloom takes special note of "those who studied constitutional law and prepared legal briefs, those who spent lonely and frustrating years, whose lives were truly dedicated to a cause."104 Although his focus remains on the students, the lesson is universal. The moral education in the "imperatives of our theory and historical practice, without which there would have been no problem and no solution,"105 enabled courts to perform their statesmanlike, if not heroic, duty.

\section{b. Education}

Bloom argues that the university must bear the burden of supporting the life of reason in a democracy. ${ }^{106}$ That life, Bloom asserts, requires, above all, "the presence of alternative thoughts. . . . [for f]eelings are largely formed and informed by convention. . . . [while r]eal differences come from difference in thought and fundamental principle."107

Bloom considers a democratic regime to be a threat to intellectual freedom. First, all regimes tend to make "an official interpretation of the past that makes [the past] appear defective or just a step on the way to the present regime."108 As a consequence, the perception of the past regime implicitly supports the ideology of the present one. Second, the accepted legitimacy of the people's power exacerbates the natural syco-

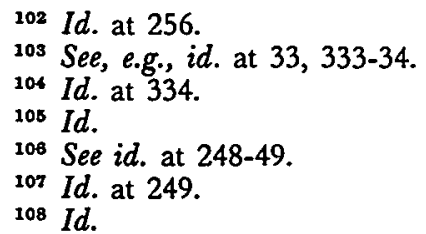


phancy toward a regime's power. ${ }^{109}$ "[T] other than the people to which a man can turn."110 Criticism of popular taste thus verges dangerously on sedition, and "democracies in their pure form hate and fear 'elitists' most of all."111 Third, the democratic regime is committed to achieving the utilitarian goal-the greatest good for the greatest number of people. ${ }^{112}$ Its emphasis is on discovering means to achieve a specific goal; the abstract analysis necessary to select those goals "seem[s] not only useless but immoral."113 Against these threats, Bloom posits that the "university is the proof that a society can be devoted to the well-being of all, without stunting human potential or imprisoning the mind to the goals of the regime."114

Bloom is less clear about what specific efforts the university should make, although he hints at the solutions he prefers. He primarily suggests "the good old Great Books approach, in which a liberal education means reading certain generally recognized classic texts, . . . trying to read them as their authors wished them to be read."115 The great books will stimulate abstract analysis by providing "an acquaintance with what big questions were when they were still big questions [and] models, at the very least of how to go about answering them." ${ }^{\text {"16 }}$ He notes finally that the "philosophic instinct" is rejecting the possibility of asking overall abstract questions in favor of "veering off toward certain branches of literature and literary criticism."117

Bloom is and has always been unwilling to separate the poets from the philosophers; ${ }^{118}$ he writes of Shakespeare as well as Socrates. ${ }^{119} \mathrm{Fi}-$ nally, however, Bloom returns to Plato's Republic, with its picture of "the community of those who seek the truth, of the potential knowers

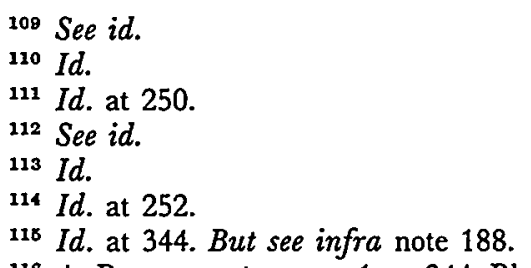

116 A. Bloom, supra note 1 , at 344 . Bloom also argues that "[ $t]$ he humanities are the specialty that now exclusively possesses the books that are not specialized, that insist upon asking the questions about the whole that are excluded from the rest of the university . . . Id. at 372 .

117 Id. at 378 (implying as an explanation of this shift that literary studies offer an extra measure of "the exhilarating presence of the [philosophic] tradition"); see also id. at 255 ("For modern men who live in a world transformed by abstractions and who have themselves been transformed by abstractions, the only way to experience man again is by thinking these abstractions through with the help of thinkers who did not share them . . ...").

118 See A. Bloom, supra note 77 , at 5-6

11 See A. Bloom, supra note 1, at 380; A. Bloom, supra note 118 , at 3. 
. . . the only real friendship, the only real common good."120

Allan Bloom is not a student of jurisprudence; his thoughts are of more abstract issues than privacy rights and life-tenured judges. Yet the main theme of his book, that people want to know what they are doing and to be good, ${ }^{121}$ as well as its subtext, that moral leadership rests on material security combined with philosophical and literary education, demand the rejection of interpretivism and lead to the main thrust of this paper. If judges, within their limited sphere, are to play a role of moral leadership in the society, what is our responsibility as legal educators $^{\mathbf{1 2 2}}$ to equip them for the role?

\section{The Poet and the State: Another Pass at Law and LITERATURE}

Plato would have banned the poets; ${ }^{123}$ Aristotle allowed them their cathartic function; ${ }^{\mathbf{1 2 4}}$ but each recognized the poets' power. Indeed, the separation of the substance of literature from the business of life and, particularly, from that aspect of life represented by the legal profession is a relatively recent development. In a very informative book, Robert Ferguson has described the highly literate bar that dominated the legal profession between 1765 and $1840 .{ }^{125}$ Following their preeminent role in drafting the critical documents to found the Republic, these lawyerintellectuals displaced the clergy as leaders ${ }^{\mathbf{1 2 6}}$ and established stability in the new republic after years of rebellion and war. ${ }^{127}$ In each of these

120 A. BLoom, supra note 1 , at 381.

121 See id. at 22.

122 Bloom says the university has only four years to educate Bloom's hypothetical student, "between the intellectual wasteland he has left behind and the inevitable dreary professional training that awaits him after the baccalaureate." Id. at 336. Not all professions are the same, however, and we, as the educators of our profession, need not accept Bloom's stricture. Indeed, if lawyers in general and judges in particular are to play their leadership role, we must not accept those limits.

${ }^{123}$ See The Republic of Plato 368 (bk. X, *595) (A.D. Lindsay trans. 1957) ("[I refer to] our refusal to admit all imitative poetry. Now that we have distinguished the different elements of the soul, it appears, I think, to be more obvious than ever that this refusal should be absolute . . . [A]ll such things seem to pollute the understanding of those who hear them. . . .")

${ }^{124}$ See ARISTotle's Poetics 50, 72 (J. Hutton trans. 1982) ("Thus, Tragedy is an imitation of an action that is serious, complete, and possessing magnitude; in embellished language, each kind of which is used separately in the different parts; in the mode of action and not narrated; and effecting through pity and fear [what we call] the catharsis of such emotions. . . . Likewise, epic poetry should include the same types as tragedy .... and should have the same essential elements . . . since an epic poem needs reversals and recognitions and sufferings." (emphasis added)).

125 See R. Ferguson, Law and Letters in American Culture 6-7 (1984).

${ }^{128}$ See id. at 9 ("[T] $]$ he lawyer came to replace the minister as the spokesman for the American culture.").

127 See id. at 15 ("Legal formulation both created and capped the conservative 
endeavors, their literary and philosophical education allowed them to invoke universal generalities to justify and buttress the new enterprise. In so doing, the American lawyer was firmly rooted in the Enlightenment tradition of unified truth. ${ }^{128}$ Evidence of this foundation is everywhere available: we can find it in John Marshall's invocation of selfevident truths in his opinions ${ }^{129}$ and in the oratory of the great courtroom battles. ${ }^{130}$

As graphically described by Lawrence Friedman, this grand tradition was grounded in the hegemony of the monied elite. The literate lawyers typically were gentlemen of leisure, born into wealthy families, and college educated. ${ }^{131}$ When American society began to evolve toward the democratic model, the bar changed with it, ${ }^{132}$ and the connection between the profession and a single social class frayed. ${ }^{133}$ Some disenchantment with enlightenment truths was perhaps inevitable as the acid of slavery began to eat away at the natural law convictions of the founders. ${ }^{134}$ The profession's separation from the tradition of liberal education was sealed with the introduction, around 1870, of the case method at Harvard Law School and the birth of legal positivism. ${ }^{135}$

American Revolution: it provided the rationale for rebellion even as it blocked the continuum of revolution with the archetypical patterns of a new order."); $i d$. at 17-18 ("In [John Adams'] $A$ Dissertation on the Canon and Feudal Law the lawyer emerges as the natural custodian of a liberty that will remain vigorous only through the dissemination of knowledge and awareness among an American citizenry."). According to Ferguson, by 1775, "Adams' views rapidly became orthodoxy disenfranchising the clergy from previous functions." Id.

${ }^{128}$ See id. at 234 (Lawyers advocated the "theory of moral value based upon Enlightenment thought.").

129 See L. Friedman, A History of American Law 113 (1973) (Marshall's opinions "purported to be timeless and nonpolitical. They appealed to principle ....").

130 See id. at 273-75 (noting eloquence of Daniel Webster, Alexander Hamilton, and others).

131 See id. at 267.

132 See R. Ferguson, supra note 125, at 202 ("[T]he law adjusted to Jacksonian impulses.").

${ }^{133}$ See id. ("As long as law reflected the order and virtue of the republic, lawyers could speak for the entire community. But once law became a deliberate instrument of social policy for particular kinds of individuals, the attorney . . . became a narrower agent for competing concerns.").

134 See id. at 234 ("The bitter debates between North and South taught lawyerpoliticians . . . that idealism complicated the task of political resolution. They learned that compromise required a language of accommodation rather than talk of higher law."). See generally R. Cover, JUSTICE ACCUSED (1975) (presenting a comprehensive study of the interaction between slavery and the natural law tradition).

${ }^{135}$ See R. FERguson, supra note 125 , at 287-88 (The introduction of the case method was a "triumph of the particular over the general. . . . The whole legal system had to be restated with microscopic intensity. . . This was legal positivism carried to its logical conclusion."). 
Thereafter, modern law gained its science and lost its humanities. ${ }^{\mathbf{1 3 6}}$

Although the ensuing century saw the lasting infiltration of some extrinsic disciplines into legal scholarship, ${ }^{137}$ the resurgence of the profession's interest in literary, imaginative representation is new. ${ }^{138}$ To date, most efforts have focused on literary strategies for understanding the profession. ${ }^{139}$ The task of educating lawyers for judging, and ultimately for providing moral leadership, demands a more ambitious undertaking. Legal education should harvest literature, as it did in the golden age of American law and literature, for literature's insights into the human condition.

${ }^{138}$ See $i d$. at 288 (The founder of the case system, Dean "Langdell[,] thought of the law as a separate science: those who entered its exclusive preserve kept to primary sources, to cases and statutes in the legal process itself."). John Ayer makes the connection between this division and the segregation of literature from the legal profession. See Ayer, supra note 9, at 895 (citing A. Douglas, The Feminization of AmeriCAN Gulture (1978)). Ayer's thesis, drawn from Douglas, is that the industrial revolution split work from the home, liberating women from economically productive work, and allowing them to evolve into the guardians of ennobling, but irrelevant higher culture. Ayer, supra note 9, at 895 n.2. If, in fact, this is the case, it is satisfying to think that the insights of feminist literary criticism might fuel the reentry to relevance. See infra notes 187-95 \& 197-201 and accompanying text.

${ }^{137}$ For instance, law and economics is hardly a new hybrid. See Hovenkamp, The Political Economy of Substantive Due Process, 40 Stan. L. Rev. 379, 401 (1988) (arguing that Lochner-era "[s]ubstantive due process was a system of law based on an economic theory"). Other "new" sciences have also found their way into the profession. Sociology figured prominently in the Brandeis brief (first submitted in Muller v. Oregon, 208 U.S. 412 (1908)) and in the doll studies cited in Brown v. Board of Education, 347 U.S. 483, 494 n.11 (1954). See also R. Kluger, Simple Justice (1976) (discussing the controversy surrounding Chief Justice Warren's use of social science studies to support Brown).

${ }^{138}$ As John Ayer expressed it, it is conventional to "lay the blame at the feet of Professor Wigmore" for the use of literature to adorn the legal profession. Ayer, supra note 9 , at 895 \& n.1. The change from adornment to arsenal is much more recent. See, e.g., Suretsky, Search for a Theory: An Annotated Bibliography of Writings on the Relation of Law to Literature and the Humanities, 32 RUTGERS L. REv. 727, 728 (1979) (recent writings interpret literature "as a source of truth which can help to analyze and criticize the law itself and define its societal role more clearly.").

${ }_{139}$ See, e.g., Ayer, supra note 9, at 895 (discussing the proposition that law and literature are not in fact two separate "disciplines"); Dworkin, Law As Interpretation, 60 TEX. L. REv. 527, 540-46 (1982) (arguing that literary interpretation, as a model for the central method of legal analysis, can improve understanding of the law); Fish, Don't Know Much About the Middle Ages: Posner on Law and Literature, 97 YALE L.J. 777, 775 (1988) (arguing that at present the study of literature has little to contribute to legal interpretation, but that this may change as "interpretive conditions" in law and literature evolve); Fiss, supra note 42, at 765 (suggesting that, to the extent that she tries "to identify principles of morality that are objective and true," the literary critic may bear some resemblance to a judge engaged in legal interpretation); Garet, Comparative Normative Hermeneutics: Scripture, Literature, Constitution, 58 S. CaL. L. REv. 35, 38, 111-15 (1985) (positing the existence of normative hermeneutics in literary criticism and constitutional law); Posner, supra note 41, at 1351 (contending that "the study of literature" can greatly "contribute to the understanding and the improvement of judicial opinions"). 
Once law is properly relocated in the humanities, a defense of the role of literature in informing a system to govern human affairs may be an act of supererogation. As John Ayer said in considering the "very idea of 'law and literature," "140 " '[m]ainstream' jurisprudence may be rich in abstract systemization, but it offers very little on the notion of what it means for a person to be good."141 The literary Iris Murdoch put it best:

Art as the great universal informant is an obvious rival, not necessarily a hostile one, to philosophy and indeed to science, and Plato never did justice to the unique truth-conveying capacities of art. The good or even decent writer ... attempts to understand and portray [other peoples'] 'world[s],' and these pictures, however modest, of other 'worlds' are interesting and valuable. . . . Art, especially literature, is a great hall of reflection where we can all meet and everything under the sun can be examined and considered. For this reason it is feared and attacked by dictators, and by authoritarian moralists . . . . The artist is a great informant, at least a gossip, at best a sage, and much loved in both roles. He lends to the elusive particular a local habitation and a name. . . . Art is far and away the most educational thing we have, far more so than its rivals, philosophy and theology and science. $^{142}$

Literature, then, is one of the sources of knowledge from which judgments about morality come, and an important participant in the dialogue from which a moral tradition is formed.

This dialogue is part of the answer to the conundrum posed in the first line of this piece ("Allan Bloom's going to be very surprised when he finds out he attracted a feminist disciple."). Professor Bloom and I disagree about many matters. Some are quite profound; for example, I believe-as this essay reflects-that no serious reader could dispute the critical role of literature by and about women in the curriculum for a liberal education. ${ }^{\mathbf{1 4 3}}$ Other differences are less profound, but still signif-

140 Ayer, supra note 9, at 895.

141 Id. at $911-12$ (footnote omitted).

142 I. Murdoch, The Fire \& THE SUN 85-86 (1977).

${ }^{143}$ But see A. Bloom, supra note 1, at 340-41 (labeling "Women's or Gender Studies" programs as part of an attempt by modern universities to hide, with "fancy packaging," the fact that they "cannot generate a modest program of general [undergraduate] education"); Bennett, Why the West?, NAT'L REV., May 27, 1988, at 38, 39 (suggesting that the selection of works based on the author's gender "trivializes the academic enterprise"). 
icant; for example, I do not believe that women of college age should be described, as they are by Bloom, as "girls," particularly when in the same sentence their male counterparts are labeled "young men."144 As to his extraordinarily vituperative criticism of feminism, ${ }^{145}$ it is in keeping with the thesis of this essay that Bloom's aversion to women writers will have left this area of his sensibilities undeveloped. In the alternative, Bloom's position may reflect that the issue of the role of women lies for him in the realm of the passions ${ }^{\mathbf{1 4 8}}$ rather than of reason, or that the formation of his social sensibilities in the immediate postwar period left this vestigial attitude, which, like similar pronouncements of much more distant societies, has not stood the test of time. ${ }^{147}$ All of this being said, however, his contribution to the dialogue remains. He has reminded us, after too long a time, that, for societies and for individuals, the quest for the good life is essential to the good life, philosophy and literature are essential to the quest, and an angry quarrel over right and wrong is superior to the silence of relativism.

To be sure, the debate over interpretivism failed to pursue systematically the sources of such a public morality. ${ }^{\mathbf{1 4 8}}$ However, the broader debate over meaning in legal decisionmaking has actually sharpened the focus on the role literature can play. For example, by taking the possibility of dispute over any legal doctrine to its absurd reduction, the Critical Legal Studies movement has elicited from its opponents an ex-

144 A. Bloom, supra note 1 , at 98.

145 See id. at $99-100$ (suggesting that "feminism ... to the extent that it presented itself as liberation [was] much more a liberation from nature than from convention or society").

146 In arguing that feminism has gone too far in its critique of traditional male sexuality, Bloom insists that "[t]he July 14 of the sexual revolution was really only a day between the overthrow of the Ancien Règime and the onset of the Terror." Id. at 101. As one commentator on Bloom expressed it recently,

Related to his limitations here is his depreciation again and again of feminist efforts. One can see that unfortunate attitudes about minorities and about women are as intermingled in $\mathrm{Mr}$. Bloom as some ideologues believe them generally to be. Here, as elsewhere, it seems that Mr. Bloom cannot help himself, which is an odd state of affairs in one so gifted. This is not to deny that women are finding that the feminist cause is more complicated than they had taken it to be, perhaps even that natural differences between women and men are more critical than some had led them to believe.

Anastaplo, supra note 2, at 261. Aristotle long ago defined passion, or feeling, to include such attributes as "desire, anger, fear, envy, courage, gladness, friendly feeling, hatred, longing, emulation, pity, and, in general, whatever is accompanied by pleasure or pain." ARISTotle, The Nicomachean Ethics 26 (Aris. Eth. 1105b21-b23) (H. Apostle trans. 1975) (emphasis omitted).

147 I am grateful to the participants in the Law and Feminism Conference, as well as to Richard Posner, for continuing to press me on this point.

${ }^{148}$ See supra notes $49-54$ and accompanying text. 
pression of the "shared intuitions"148 by which most human decisionmaking, including legal decisionmaking, progresses.

In its capacity to be at once fact-bound and concrete and yet flexible and symbolic, literature operates both on the level on which such intuitions are formed and on the level on which they are brought to point of expression. In this dual function, the use of literature closely resembles the function of common law cases in traditional legal teaching. Hegland, perhaps unintentionally, illustrates this dual function perfectly. To express his "intuition" that legal truths may be recognized intuitively, he resorts immediately to a story about intuitive recognition from Zen and the Art of Motorcycle Maintenance. ${ }^{150}$ By invoking, as $\mathrm{I}$ will in Section $\mathrm{V}$, the meaning within the rich and compelling body of literature I examine, this paper buttresses Hegland's "intuition." By furnishing a room in which intuition can play, to return for a moment to Allan Bloom, literature can help citizens, lawyers, and judges "to know what [they] are doing and to be good."181

To illustrate the potential of literature to prepare judges for moral decisionmaking, I now turn to the difficult issue of how to govern the choice regarding abortion. It seems a persuasive illustration: Robert Bork may have fallen by misreading the public temperature on the issue, ${ }^{152}$ and John Ely's conversion to interpretivism rests on what he sees as the Court's lack of legitimate resources to support its decision. ${ }^{153}$ If Bloom is correct, wise storytellers have something to say about what is the right answer to the abortion question and why it is right. Books cannot, however, speak in a vacuum. Accordingly, before discussing Jane Eyre, The Scarlet Letter, and The Handmaid's Tale, ${ }^{154}$ I will first briefly recite what the legal community of judges and scholars have said about the abortion issue in its modern incarnation.

140 See Hegland, supra note 97, at 1208 n.19. (arguing that these intuitions result in great uniformity of judgments, however "subjective" such judgments may seem).

150 R. Persig, Zen and the ARt of Motorcycle Maintenance (1974), cited in Hegland, supra note 97, at 1208 n.19.

151 See A. Bloom, supra note 1 , at 238.

152 See supra notes 56-61 and accompanying text.

${ }_{153}$ See supra notes 28-38 and accompanying text.

154 I discuss the reasons for my selection, see infra notes 187-95 and accompanying text, and discuss the works themselves, see infra notes 196-312 and accompanying text. 


\section{The Debate over Abortion}

\section{A. The Evolving Drama of Roe v. Wade}

Contrary to the aphorism that "victory finds a hundred fathers, but defeat is an orphan,"15s Justice Blackmun's majority opinion in Roe $v$. Wade ${ }^{168}$ is the victory nobody likes. Many, of course, consider it a defeat and deplore the outcome. ${ }^{157}$ Even among those who purport to agree with the outcome, few support the opinion. Some disagree for reasons of constitutional purity, ${ }^{158}$ others because the opinion lacked craftsmanship, ${ }^{158}$ and still others because the opinion shrank from what should have been its subject-the real social change in the status of women. ${ }^{160}$ Beyond cavil, the opinion lacks a certain high rhetorical tone we have come to expect from path-breaking developments in the Supreme Court. ${ }^{161}$ However, since the now-fifteen-year-old decision only began the debate, and things have traveled quite a distance since 1973, I will pause only briefly at the starting gate.

155 G. Ciano, The Giano Diaries, 1939-1943, at 521 (H. Gibson ed. 1946).

${ }_{188} 410$ U.S. 113 (1973). The vote in Roe was 7 to 2; the Court has certainly divided much more sharply on less serious questions.

167 See A. Bickel, The Morality of Consent 28 (1975) ("Should not the question ... have been left to the political process, which in state after state can achieve not one but many accomodations, adjusting them from time to time as attitudes change?"); see also M. GLENDON, ABORTION AND DIVORGE IN WESTERN LAW 40-58 \& nn. 149-206 (1987) (surveying reactions to Roe v. Wade).

${ }^{158}$ See J. ElY, supra note 11, at 14-15, 21; Ely, Wages, supra note 34, at 93536. Even Professor Ely's early, purportedly formalist attack on Roe, however, reveals, despite his disclaimers, his real gut "unhappiness" with the decision on the merits. Compare id. at 926 ("Were I a legislator I would vote for a statute very much like the one the Court ends up drafting.") with id. at 924 (describing the anti-abortion laws as striking a balance between "cramp[ing] the lifestyle of an unwed mother" and "end[ing] (or if it makes a difference, prevent[ing]) the life of a human being").

${ }_{108}$ See Perry, supra note 41, at $733 \mathrm{n} .203$ (arguing that the Court's use in Roe of the "right to privacy" was unacceptable and confused the opinion); Regan, supra note 40, at 1571-79 (attempting to ground doctrinally Court's result in Good Samaritan law).

${ }_{160}$ See Karst, supra note 15, at 58 (suggesting that abortion is "an issue going to women's position in society in relation to men"); MacKinnon, Privacy v. Equality: Beyond Roe v. Wade (1983), reprinted in C. MACKInNon, FEMINISM UNmodified 93-102 (1987) (seeking to "situate abortion and the abortion right in the experience of women"); Tribe, supra note 40, at 335 (attempting to understand the abortion right as a response to the subordinate position in which women are placed when they confront unwanted pregnancy and motherhood).

161 See Henderson, Legality and Empathy, 85 Mich. L. Rev. 1574, 1625, 1629 (1987) (criticizing Roe and subsequent abortion decisions for focusing on legalisms and giving short shrift to the suffering of women in society). Indeed, so laconic is the opinion that, particularly after a prolonged immersion in the works of Allan Bloom, one is tempted to address it as a piece of secret writing, see A. BLoom, supra note 1, at 311, intended to preserve the Court from the popular branches. Had Roe succeeded as secret writing, it would, of course, have been the end of the abortion controversy. 
Roe v. Wade struck down as unconstitutional the abortion law of the state of Texas, which prohibited abortions except to save the woman's life. In deciding Roe and its companion case, Doe v. Bolton, ${ }^{\mathbf{1 6 2}}$ the Court by extension invalidated the regulatory schemes of all the other states. $^{163}$ The opinion makes two points: women have a fragile right to decide whether or not to terminate a pregnancy, and the state has authority to place certain limits on this right. Justice Blackmun begins by articulating the theme of the fragile right:

This right of privacy, whether it be founded in the Fourteenth Amendment's concept of personal liberty and restrictions upon state action, as we feel it is, or, as the district court determined, in the Ninth Amendment's reservation of right to the people, is broad enough to encompass a woman's decision whether or not to terminate her pregnancy. ${ }^{164}$

Having established, however hesitantly, the right, the Court immediately disclaims its force: "The privacy right involved[] . . . cannot be said to be absolute."165 The rest of the opinion explores the boundaries of the right, which is limited by the state's interest in maternal health ${ }^{168}$ and "potential life."167 States could pass regulations protecting maternal health during pregnancy, the Court speculates, if they restrict the regulations to after the first trimester of pregnancy-the point at which the Court argues abortion was no longer safer than childbirth. ${ }^{168}$ Second-and without much explanation-the Court concluded that regulation protecting the state's interest in potential life, including the prohibition of life, could be justified at viability "because the fetus then presumably has the capability of meaningful life outside the mother's womb."169

As one commentator cogently expressed it, "The Court's decision in Roe has been trashed in countless articles and law school classrooms." 170 Outside the classroom, state and federal legislatures have

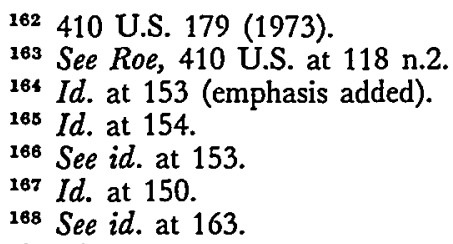

169 Id. Insofar as this much-debated language is capable of being understood, the Court seemed to assume that its position could rest on its previous point that the history of philosophy and religion reflected no consensus on when life begins. See id. at 160-63.

170 Henderson, supra note 161, at 1620 n.296; see, e.g., Ely, Wages, supra note 34, at 939-40 (disparaging Roe as "Lochnerism"); Epstein, Substantive Due Process by 
also persistently tested the resilience and limits of the decision. As a result, in the fifteen years since Roe $v$. Wade, the Supreme Court has addressed governmental restrictions on abortion in twelve full opinions. ${ }^{171}$ Over this period, the debate in the Court has sharpened. Only Justices White and Rehnquist dissented from Roe and Doe, ${ }^{172}$ but those decisions represented high tide for Court unity on the abortion question. ${ }^{173}$ The Court split four to four on the latest decision. ${ }^{174}$

At this moment of equipoise on the Court, it is impossible to say whether the Roe $v$. Wade glass is half full or half empty. The opinion in Roe is the law and has been for fifteen years. ${ }^{175}$ If, as I suspect, the defeat of Robert Bork was at some level a referendum on Roe v. Wade, the returns are now in. It's been fifteen tough years, though, and the opinion-if not the holding-provided little ammunition for advocates of the Justices' role as moral leaders. Indeed, by failing to articulate the

Any Other Name: The Abortion Cases, 1973 Sup. CT. REv. 159, 185 (criticizing Roe "and the entire method of constitutional interpretation that allows the Supreme Court . . . both to 'define' and 'balance' interests on the major social and political issues of our time").

171 See Thornburgh v. American College of Obstetricians \& Gynecologists, 476 U.S. 747 (1986); Simopoulous v. Virginia, 462 U.S. 506 (1983); Planned Parenthood v. Ashcroft, 462 U.S. 476 (1983); Akron v. Akron Center for Reproductive Health, 462 U.S. 416 (1983); H.L. v. Matheson, 450 U.S. 398 (1981); Harris v. McRae, 448 U.S. 297 (1980); Colautti v. Franklin, 439 U.S. 379 (1979); Bellotti v. Baird, 443 U.S. 622 (1979); Maher v. Roe, 432 U.S. 464 (1977); Beal v. Doe, 432 U.S. 438 (1977); Planned Parenthood v. Danforth, 428 U.S. 52 (1976); Connecticut v. Menillo, 423 U.S. 9 (1975).

172 See Roe, 410 U.S. at 171 (Rehnquist, J., dissenting); Doe, 410 U.S. at 221 (1973) (White, J., dissenting in both Doe and Roe); id. at 223 (Rehnquist, J., dissenting).

${ }^{173}$ But of. Bellotti, 443 U.S. 622, 651 (overruling Massachusetts law requiring minors to obtain parental consent before undergoing an abortion). In Bellotti, eight Justices voted to overturn the statute, but the Court divided sharply on underlying principles. Three Justices joined Justice Powell's opinion holding that the consent requirement could be an absolute, possibly arbitrary veto of a judicially authorized abortion. Justice Stevens, joined by Justices Brennan, Marshall, and Blackmun, concurred in the outcome but refused to join the majority because it discussed ways in which a future law could be constructed to survive constitutional scrutiny. See id. at 656 (Stevens, J., concurring).

${ }_{174}$ See Hartigan v. Zbaraz, 108 S. Ct. 479 (1987) (mem. per curiam). Justice Kennedy's record on the matter is essentially blank. See N.Y. Times, Dec. 15, 1987, at B16, col. 1 (Justice Kennedy "sidestepped a question on what standards he would use deciding whether to overrule Roe v. Wade .... ."); N.Y. Times, Nov. 15, 1987, § 1, at 5 , col. 4 (commenting that the "question of what Judge Kennedy would do about .. . [the issue of abortion] is . . . wide open"). Justice Kennedy's vote becomes critical because the Court will most certainly continue to revisit the abortion issue in general and Roe in particular. See M. GLENDON, supra note 157, at 42 ("Vigorous pursuit of an [anti-abortion] amendment along with several other factors has made the prospect of the Supreme Court's eventual re-examination of Roe and its progeny increasingly thinkable.").

175 Indeed, the quibbling with the opinion in Roe may reflect the luxury of a long period free of back alley abortions. 
moral claims of the decision, the opinion yielded to its opponents the moral high ground. ${ }^{176}$

\section{B. Moral Issues in the Abortion Decision}

To date, only women can become pregnant and reproduce the species. Each member of the species, once separated from the woman, is individually so valuable that we are reluctant to permit one member to take actions we foresee will end the life of another. To the extent that any woman can terminate her pregnancy at will, moreover, the continuity of the species may be jeopardized. The only way to ensure the continuity of the species or the value of the potential individual is to compel fertile women to carry pregnancies to term.

On the other hand, pregnancy entails nine months of physical intrusion, health implications, danger, pain-and at least nine months (and often a lifetime) of social consequences, economic sacrifice, and psychological and emotional commitment. Because of the progress of medical science, no woman must carry a pregnancy to term. Only law can compel that end. When a woman seeks to terminate a pregnancy, laws limiting her access to abortion preempt her individual decision with one that is socially imposed. Finally, the socially imposed decision falls on a group historically disadvantaged in access to the social power that determines such decisions. ${ }^{177}$

\section{G. Female Autonomy in Patriarchal Society}

Any decision of who should determine a woman's pregnancy inevitably involves, then, a determination of the value of individual, and specifically female, autonomy. Roe $v$. Wade did not articulate the issue in gender terms. ${ }^{178}$ Since this is an essay about abortion rather than Roe,

${ }^{178}$ See Doe, 410 U.S. at 221 (White, J., dissenting from Roe and Doe) (condemning the majority opinion as an "improvident and extravagant" exercise of "raw judicial power" in a "sensitive area" in which "reasonable men may easily and heatedly differ"); see also M. GLENDON, supra note 157, at 42 ("There is no evidence at all that 'conventional moral culture' validates the fundamental and radical message of Roe and Doe."). As Professor Law points out, even the defenders of the decision are morally ambivalent. See Law, Rethinking Sex and the Constitution, 132 U. PA. L. REv. 955, 1021-23 (1984).

177 See generally F. Jaffe, B. Lindheim \& P. Lee, Abortion Politics: PRivate Morality and Public Policy 127-38 (1981) (discussing the class politics of the controversy surrounding public funding of abortion); K. LUKER, ABORTION AND THE POLITICS OF MOTHERHOOD 15-39 (1984) (arguing that 19th century state laws restricting abortion (still on the books until $R o \varepsilon$ ) derived from the political influence of "elite" physicians and the relative political weakness of women).

${ }_{178}$ Many commentators have criticized this oversight. See, e.g., MacKinnon, supra note 160, at 93-102 (rejecting privacy doctrine of Roe in favor of an abortion 
Justice Blackmun's lens need not become ours. Nonetheless, in light of this divergence in the inquiry, I will briefly outline the argument for not following the Court's lead.

Laws compelling pregnancy can, by definition, fall on only one sex. Legal prohibitions of abortions, therefore, imply a gender distinction between those who are capable of becoming pregnant and those who are not. Alternatively, one may treat the issue as analogous to existing pregnancy and draw the universe as all pregnant people (women) versus all nonpregnant people (women and men). The Court articulated this distinction in its early maternity leave decisions, holding that exclusion of medical conditions associated with maternity from medical benefits did not apply to nonpregnant women and thus did not violate the fourteenth amendment ${ }^{178}$ or the Civil Rights Act of $1964 .{ }^{180}$

Upon reflection, it seems counterintuitive to suggest that a disadvantage must apply to each member of the disadvantaged class to be discriminatory ${ }^{181}$ As one recent commentator points out, "Criticizing [the pregnancy benefits decisions] . . . has . . . become a cottage industry",182 the cases are not followed. ${ }^{183}$ As will be set forth below, opinions differ about why this insight was not carried over into the abortion issue. ${ }^{184}$ Assuming, however, that later commentators are correct, an inquiry into the role of female autonomy is in order.

That moral inquiry is not simple. However, works of literature can help even Justices "know what they are doing and be good [judges]." ${ }^{\text {185 }}$ To be good judges in the abortion matter requires per-

right grounded "in the experience of women"); Regan, supra note 40, at 1569, 1636-44 (criticizing the privacy right basis of $R o e$ and proposing a gender-based equal protection analysis to support a right to abortion).

179 Geduldig v. Aiello, 417 U.S. 484, 496 n.20 (1974) (upholding a California disability insurance system which did not allow compensation for certain disabilities related to pregnancy).

${ }_{180}$ General Electric v. Gilbert, 429 U.S. 125, 133-40 (1976) (refusing to uphold a challenge under 42 U.S.C. $\S 2000 \mathrm{c}-2(\mathrm{a})(1)$ (1982) to company disability plan which denied compensation for disabilities arising from pregnancy).

${ }_{181}$ As Justice Stevens so cogently expressed it, "Insurance programs, company policies, and employment contracts all deal with future risks rather than historic facts. The classification is between persons who face a risk of pregnancy and those who do not." Gilbert, 429 U.S. at 161 n.5 (Stevens, J., dissenting).

${ }^{182}$ Law, supra note 176, at 983.

183 See L. Tribe, AMERICAN Constitutional LAw § 16-29, at 1579-81 (2d ed. 1988). Congress rendered moot the holding in Gilbert by amending the Civil Rights Act. See Pregnancy Discrimination Act, Pub. L. No. 95-555, 92 Stat. 2076 (1978) (codified as amended at 42 U.S.C. $\S 2000$ e (1982 \& Supp. IV 1986)). Thus, as a technical matter, courts are ignoring Gilbert's analysis, rather than its precedent.

184 See supra notes 240-44 and accompanying text. Considering the ferocity of the attack on Roe and the dwindling support for the position on the Court, a beleaguered judiciary is understandably reluctant to change horses in midstream.

${ }_{185}$ See supra text accompanying notes 100-05. 
forming two of the hardest tasks of human thought: to tie the law to human experience and to hear the voice of the other. ${ }^{188}$ For each of these purposes, fictional works of genius may greatly assist them.

\section{Qualifying our Witnesses: Brontë, HawTHORne, AND ATWOOD}

My selection of Jane Eyre, The Scarlet Letter, and The Handmaid's Tale immediately raises questions of selection criteria. Indeed the definition and interpretation of the canon of great literary works is one of the hottest disputes between Bloom ${ }^{\mathbf{1 8 7}}$ and his followers on one side and almost every liberal or feminist scholar in any field on the other. ${ }^{188}$ I do not need to, and therefore will not, challenge Bloom's entire position regarding works worthy of study. My position for purposes of this analysis is simply that women are sentient creatures whose capacity for a good life is inherently the same as that of men. I, there-

${ }^{188} \mathrm{I}$ am profoundly indebted for the recent compelling expression of this idea, obviously central to my thinking here, by Professors Henderson and Minow. See Henderson, supra note 161, at 1576-77 (arguing that judicial and academic "empathy can contribute to meaning and interpretation and enlarge the universe of legal discourse and understanding"); Minow, Justice Engendered, 101 HARv. L. REv. 10, 15 (1987) (stating that "[t]he task for judges is to identify vantage points, to learn how to adopt contrasting vantage points, and to decide which vantage points to embrace in given circumstances").

${ }_{187}$ See A. Bloom, supra note 1, at 65-66; Armistead, Education Secretary William Bennett and Author Allan Bloom, Conservative Dig., Apr. 1988, at 25, 27-28.

${ }_{188}$ Discussions of the current battle to define the canon of great works at Stanford University are legion. See, e.g., Bennett, supra note 143, at 37-38 (the inclusion of works by women and minorities in the Western Culture curriculum at Stanford exemplifies Bloom's "closing of the American mind"); Bowen, The Canon Under Fire, TIME, Apr. 11, 1988, at 66, 66-67 (summarizing conflicting evaluations of Stanford's action); Fairbia, Washington Diarist: Huffing and Puffing, THE NEw REPUBLIC, May 23, 1988, at 43, 43 (criticizing the conservative position at Stanford and noting the value of minor works); Gates, Say Goodnight, Socrates, NewSwEEk, Feb. 1, 1988, at 46, 46 (describing Stanford's new curriculum requirements and questioning its decision).

For more general discussions of great works for the college curriculum, see, e.g., Salmagund, Fall 1986 (issue devoted to the subject, subtitled "On Cultural Literacy: Canon, Class, Curriculum"); Heller, Scholars Defend Their Efforts to Promote Literature by Women and Blacks, Decry Attack by Bennett, CHRON. Higher Educ., Feb. 17, 1988, at A1, A16 (charging Secretary Bennett with mischaracterizing efforts to broaden the curriculum as efforts to eliminate the reading of classic texts); Macintyre, Traditions and Conflicts, Liberal EDuc., Nov.-Dec. 1987, at 6, 9-10 (discussing the difficulty of defining the tradition from which a course on Western Culture might draw); Wilson, Bennett: Colleges' "Trendy Lightweights" Replace Classics with Nonsense, Chron. Higher Educ., Feb. 10, 1988, at 19, 27 (reciting Bennett's belief that arguments for change in the curriculum "look like they spring from Groucho Marx," and damage the reputation of higher education); Atlas, The Battle of the Books, N.Y. Times, June 5, 1988, $\S 6$ (Magazine), at 24,26 (surveying the various viewpoints advocating changed standards for canonization). 
fore, simply apply to literature by and about women (either in whole or in part) the same criteria that others have validly applied to works by and about men. My position is not one of cultural relativism; literature by and about women addresses ultimate questions of moral philosophy, such as the meaning of autonomy and citizenship and freedom and responsibility, that are entitled to serious consideration under very traditional standards of importance.

I will not simply recommend the stories. As Professor Bloom's book reflects at so many points, one can be well read and still not entirely wise. ${ }^{189}$ Instead, I will attempt to retell them. ${ }^{180}$ In this exercise, I do not claim to rewrite the texts; the freedom of deconstruction is inimical to the premise that they hold implicit moral meaning. ${ }^{191}$ Rather, pursuing Ms. Murdoch's image, I wish to examine and consider some of the objects in the hall of reflection these rich imaginings present.

Although the three novels I've selected are by no means the only works that might have supported the moral dialogue I pursue, each meets the basic criteria for serious literature. They treat the "permanent and general aspects of human nature and institutions,"192 and have withstood the test of time. ${ }^{193}$

Each work most strongly illustrates one of three issues. First, the works create empathy for persons situated differently from the reader. When the speaker is part of a group historically excluded from decisionmaking arenas, this is a particularly valuable function. ${ }^{194}$ Jane Eyre best illustrates this function. Second, the works weave situations of moral possibility with sufficient ambiguity for the exercise of moral dialogue and, one hopes, resolution. The Scarlet Letter, with its conscious political themes of autonomy and community at the founding of a new

189 See, e.g., A. BLoom, supra note 1, at 21 ("It is foolish to believe that book learning is anything like the whole of education . . . .").

180 I am indebted to Professor Carol Rose for articulating the insight that this article retells existing stories for pedagogical purposes, rather than merely recommending them.

191 See A. Bloom, supra note 1, at 379 ("Deconstructionism . . . is the last, predictable, stage in the suppression of reason and the denial of the possibility of truth in the name of philosophy. The interpreter's creative activity is more important than the text; there is no text, only interpretation ..... A cheapened interpretation of Nietzsche liberates us from the objective imperatives of the text that might have liberated us from our increasingly low and narrow horizons.").

192 R. Posner, Law and Literature: A Misunderstood Relation 15 (1988).

193 Although The Handmaid's Tale is rather recent, the utopian genre, which it represents here, is old. See infra note 195 and accompanying text.

194 See Henderson, supra note 161 , at 1575 n.5 (discussing the role and importance of empathy in the decisionmaking process of civil rights and civil liberties cases). 
society, is the richest such moral case study. Third, the works sufficiently vary the context of the debate from that of everyday life to allow an escape from unexamined assumptions that otherwise would constrain the discussion. Here, the utopian and dystopian genres (the latter exemplified by The Handmaid's Tale) have historically functioned as effective vehicles. ${ }^{195}$

\section{LITERature, Women, and Gitizenship}

\section{A. Woman's Autonomy: Jane Eyre}

Although Victorian England is widely acknowledged as the paradigm of patriarchal society-law, education and social custom combining to cut women off from all but the most meager opportunities for autonomous life $\mathrm{e}^{198}$ - perhaps the paradigm case is the place to begin. It has, at any rate, a certain perverse appeal.

Not to diminish Susan B. Anthony, but Jane Eyre is really "the mother of us all."197 When Sandra Gilbert and Susan Gubar had to choose one nineteenth century novel to reproduce in full for The Norton Anthology of Literature by Women, ${ }^{198}$ they chose Jane Eyre, the same work that inspired the title for their pathbreaking critical reassessment of nineteenth century literature, The Madwoman in the Attic. ${ }^{189}$ As a contemporary diarist presciently recognized, "the most alarming revolution of modern times has followed the invasion of Jane Eyre." ${ }^{200}$ To understand the story of her journey to maturity is to hear the story of women seeking autonomy in patriarchal society shouted

${ }^{195}$ Starting, of course, with Plato's Republic, supra note 123, Utopian literature provides an imaginative positive model for the present. See, e.g., T. MORE, UTOPIA (1516); H. G. Welis, A Modern Utopia (1904); see also M. BUber, Paths IN UTOPIA 7 (R. Hull trans. 1950) ("The vision of 'what should be'. . . [is] inseparable from a critical and fundamental relationship to the existing condition of humanity."); W. Galston, Justice and the Human Good 13-54 (1980) (defending Utopian political theory for political philosophy). It is perhaps a mark of our century that we specialize in its opposite: G. ORWELl, NINETEEN EIGHTY-Four (1949), A. HuXLEX, Brave New World (1932), and A. Burgess, A Glockwork Orange (1962) all exist as warnings, rather than exhortations.

${ }^{186}$ Cf. Karst, Woman's Constitution, 1984 Duke L.J. 447, 459-60, 475-80 (noting that stereotypes of women, expressed and reinforced in law and custom, make true autonomy for women difficult to achieve).

197 V. Thomson, The Mother of Us All (1947).

198 The Norton ANThology of LIterature by Women (S. Gilbert \& S. Gubar eds. 1985) [hereinafter The NorTON ANTHOLOGY].

199 S. GilberT \& S. Gubar, supra note 21.

200 The NoRton ANTHOLOGy, supra note 198, at 347 (quoting Victorian journalist Margaret Oliphant). 
loudly ${ }^{201}$ and from a "literature of their own."202 What, then, does Jane Eyre tell us about the morality of consigning women to a status of reduced autonomy?

We learn in Ghapter I that not only is Jane Eyre a female and thus already of reduced status in Victorian England, she also lacks the critical assets for a female to survive in society: she is plain, poor, and unconnected-an orphan living with her dead uncle's widow and children. Of these drawbacks, she seems most concerned about her selfproclaimed "physical inferiority," the most important attribute to her success in the sexual marketplace of a patriarchal society. ${ }^{203}$

Although each of her three cousins joined to make her youth a torment, she finally fights back only when attacked by the boy. As punishment for her rebellion she is locked in the blood-red chamber in which her uncle had lain in state. Shut up in the claustrophobic red room, she fantasizes escape from her uncle's house through the passively self-destructive routes of starvation and flight; in the actual event of the red room she takes a third destructive path: madness. ${ }^{204}$

Her hysteria leads to her release from the avuncular household at Gateshead and the beginning of her Bildungsroman-her journey to maturity and self-realization. The journey begins, appropriately enough, with her first autonomous decision. Asked by the kindly apothecary, whose services were invoked by her illness, whether she would go to her father's reputedly impoverished family or to a school, she chooses the school. She is not "heroic enough to purchase liberty at the price of caste," plishments attained by [the] . . young ladies ... beautiful paintings of

201 See N. Auerbach, supra note 21 , at xvii ("In her militant moods, Charlotte Brontë shouts at [the reader].").

202 The phrase is Elaine Showalter's, see E. Showalter, supra note 21, drawn from Virginia Woolf, see V. Woolf, A Room of ONE's OwN (1929). Showalter, now a Professor at Princeton, was one of the first wave of feminist literary critics. See Kolbert, supra note 21, at 112.

${ }^{203}$ Barely two paragraphs into the book, Jane proclaims her "physical inferiority" to her handsome cousins. See C. BRONTË, supra note 18, at 351 (ch. 1). Jane's physical unmarketability is a strong, recurrent theme. From her appearance at about ten until the novel effectively ends with her marriage at twenty, whenever the issue of sexual love or competition or jealousy arises, the rival is always gorgeous and the act of loving Jane always accompanied by a rejection of beauty as a value. See, e.g., id. at 585-88 (ch. 25) (Jane describes herself to Mr. Rochester as one who can bring "neither fortune, bounty, nor connections" to her husband); $i d$. at 480-85 (ch. 16) (Jane and a companion assess the qualities of a suitor for Mr. Rochester: Miss Ingram, a woman, "[t]all, fine bust, sloping shoulders, long, graceful neck; olive complexion.").

204 See id. at 355-62 (chs. 2-3). We do not actually witness her madness, but, after her screams at thinking she sees a ghost failed to effectuate her release, she awakens in the nursery and assumes from her treatment that she must have had some sort of a fit. ${ }^{205}$ Id. at 367 (ch. 3). 
landscapes and flowers by them executed; ... songs they could sing and pieces they could play, ... purses they could net, ... French books they could translate"206 seemed like "an entrance into a new life."207 Unable to hold her own in the.world of beauty and riches, she reaches for accomplishment.

Seeking a life of achievement, she learns that she may indeed achieve only the starvation she anticipated. For the school, run by the Dickensian Reverend Brocklehurst, is an utterly impoverished universe; the girls are frozen, starved, beaten, and stripped of their sexual identity (they wear identical, shapeless uniforms and are shorn of their hair). Hence the second of Jane's lessons: the lack of the assets to succeed in the sexual marketplace reduces her to sexless deprivation in the world of accomplishments. ${ }^{208}$

A typhus epidemic brings Reverend Brocklehurst's flirtation with sexual sadism too close to murder. Outsiders intervene, and conditions ease. The story resumes eight years later, when, at eighteen, Jane tires of the all-female world of the school and longs for a wider experience. $^{208}$

This time, she does not court starvation in her flight, but, still "unconnected," she can obtain other employment only through the anonymous means of advertising in the newspaper. (That her advertisement brought but one response should have alerted her to the possible irregularities in the respondent, but, oblivious, she sets off for Thornfield Hall.) This third stop in her pilgrimage is patriarchal society writ large: Jane describes the absentee owner as "Mr. Rochester . . . a gentleman, a landed proprietor" whose housekeeper "wonder[s] at my wish to gain a more definite notion of his identity."210 Thornfield, like the school Jane left, is occupied essentially by women: the housekeeper runs the establishment, and Jane tutors a little French girl, the obvious harbinger of the news of Rochester's sexual misadventures. A third female inhabitant is Grace Poole, a mysterious, stolid woman who supposedly spends her days sewing in the attic, whence come occasional peals of maniacal laughter. ${ }^{211}$

Soon after her arrival at Thornfield, Jane makes her first overtly political statement and takes up pacing the attic: "[T]he restlessness

${ }^{208} I d$.

207 Id.

208 See id. at 380-401 (chs. 5-7).

208 See id. at 411-20 (chs. 9-10). At this critical juncture, a servant from Gateshead visits her and, viewing her after an eight year absence, opines, "[I]t is as much as ever I expected of you: you were no beauty as a child.' "Id. at 424 (ch. 10).

210 Id. at 437 (ch. 11).

211 See id. at $438-39$. 
was in my nature; it agitated me to pain sometimes. Then my sole relief was to walk along the corridor of the third story, backwards and forwards, safe in the silence and solitude of the spot . . .."212

She philosophizes:

Women are supposed to be very calm generally: but women feel just as men feel; they need exercise for their faculties and a field for their efforts as much as their brothers do; they suffer from too rigid a restraint, too absolute a stagnation, precisely as men would suffer; and it is narrow-minded in their more privileged fellow-creatures to say that they ought to confine themselves to making puddings and knitting stockings, to playing on the piano and embroidering bags. It is thoughtless to condemn them, or laugh at them, if they seek to do more or learn more than custom has pronounced necessary for their sex. ${ }^{\mathbf{2 1 3}}$

Thinking these rebellious thoughts, she recalls that she "not unfrequently heard Grace Poole's laugh: the same peal, the same low, slow ha! ha! which, when first heard, had thrilled me: I heard, too, her eccentric murmurs; stranger than her laugh.".214

Jane's desire for adventure is well satisfied when her employer, Edward Rochester, appears on the scene. In his presence, the manifestations of the madwoman in the attic intensify. In the space of a few short months, Jane rescues him from a fire set in his bedchamber and helps him nurse a guest who has been attacked with a knife. Most important, of course, she finds herself romantically attracted to him. ${ }^{215}$

For all its Byronic romance, however, the relationship is a power struggle from the beginning. ${ }^{216}$ When his teasing is at its worst-he threatens to send her away on account of a fictional pending marriage-she equates her rejection immediately with her assets: " And if God had gifted me with some beauty and much wealth, I should have

212 Id. at 440 (ch. 12).

213 Id.

214 Id. at 441 . The connection between Jane's rebellious character and the madwoman in the attic is, of course, Gilbert and Gubar's. See S. GiLberT \& S. Gubar, supra note 21, at 348 ("Thornfield's attic soon becomes a complex focal point where Jane's own rationality ... . and her irrationality (her 'hunger, rebellion and rage') intersect."). The association between the madwoman and Jane's political statement is mine. 20).

${ }_{215}$ See C. BRontë, supra note 18, at 474, 481-85, 496 \& 526-27 (chs. 15-17,

${ }^{218}$ As Gilbert and Gubar point out, at the first meeting between Jane and Rochester, he accuses her of bewitching his horse, an exercise of her power that resulted in his twisting his ankle. See S. GILBERT \& S. Gubar, supra note 21, at 351-52. 
made it as hard for you to leave me, as it is now for me to leave you." "217 She even seeks to cast off her inadequate flesh and claim her common humanity with the Lord of the manor: "I am not talking to you now through the medium ... of mortal flesh - it is my spirit that addresses your spirit; just as if both had passed through the grave, and we stood at God's feet, equal, — as we are!' "218

Not surprisingly, once secure in his marriage proposal, she immediately begins to fear losing her separate identity. Their first exchange is again over physical beauty. The morning after proposing, he praises her for her hazel eyes (she notes parenthetically that they are green). She begins to realize that it's not her he sees, but rather an image of her in his own mind. ${ }^{219}$ Worse, his image of her immediately begins to slide toward the essential Victorian patriarchal image of an "angel."220 She resists: " 'I am not an angel, . . . and I will not be one till I die: I will be myself. Mr. Rochester, you must neither expect nor exact anything celestial of me - for you will not get it . . . ." "221

Struggling to maintain a foothold of identity, she recalls that a visitor from Gateshead had brought news of a prosperous uncle from her supposedly impoverished father's family. Indeed, the uncle had indicated an intention to adopt her. Although she knew about this possibility of escape from her poverty and orphanage for months, she essays a letter only after her independence is threatened by Rochester's proposal. She explains, " "II]f I had but a prospect of one day bringing Mr. Rochester an accession of fortune, I could better endure to be kept by him now.' "222

The letter indeed liberates her from her impending marriage, but not as she foresaw. It turns out that her uncle is connected to the family of Rochester's first wife, Bertha Mason Rochester, the "Madwoman in the Attic." At the uncle's behest, a lawyer appears to stop the marriage ceremony, and, rather than becoming Mrs. Rochester, Jane is obliged

${ }^{217}$ C. BRONTË, supra note 18 , at 563 (ch. 23).

218 Id.

219 After informing the reader of Rochester's mistake, Jane adds, "you must excuse the mistake." Id. at 567 (ch. 24). It quickly becomes clear that she does not excuse it:

'Don't address me as if I were a beauty; I am your plain, Quakerish governess.'

'You are a beauty, in my eyes ....'

'You are dreaming, sir, - or you are sneering.'

Id. at 568 (ch. 24).

220 Id. at 569 .

221 Id.

222 Id. at 577. 
to confront her. ${ }^{223}$

When the attic door opens, Jane confronts a female, large enough almost to "equal[] her husband,"224 running backward and forward in her prison. Bertha Mason's role as Jane's Doppelgänger is by now a staple of feminist literary criticism, ${ }^{225}$ but it is of sufficient power to bear repeating. When Jane is feeling rebellious, she is drawn to the attic, where she paces back and forth and meditates on a different society. Jane's vulnerability to her sexual feelings about Rochester are embodied in Bertha, whose sexual and other "excesses had prematurely developed the germs of insanity" inherited from her mother. ${ }^{226}$ When Jane Eyre is about to be smothered in the strange wedding veiling of Jane Rochester, Bertha tears up the hated bond. Jane Eyre's rebellious refusal to accept the restrictions of the world in which she finds herself, a refusal that introduces her in Chapter I of her story, takes the form in the critical central episode of the novel of a madwoman-a grovelling, growling, grizzled animal, who must be restrained with ropes, lest she destroy the house. ${ }^{227}$

Marriage now impossible, Rochester proposes the deal he was offering Jane all along-hiring her as a mistress, "the next worst thing to buying a slave"228 as he damningly recalls while reviewing his profligate past. She refuses, of course, and, predictably, takes flight again. ${ }^{229}$

Having confronted the madness of surrender, this time Jane flees further than ever before toward denial culminating in near starvation. Abandoning the prospect of the uncle's legacy and with only a few shillings in her handkerchief, she cannot find employment and soon finds herself starving and exposed. As she resigns herself to dying, she is offered her last chance to accommodate herself to the world of men in the form of St. John Rivers, a clergyman of impeccable character and visage, who picks her up from his doorstep. ${ }^{230}$

${ }^{223}$ See id. at 594-98 (ch. 26). Actually, this is not their first meeting. A few days before the wedding, Bertha had gotten out and made a midnight visit to Jane's room, rending in pieces the veil Rochester had given her for the ceremony while Jane watches. See id. at 589-91 (ch. 25).

224 Id. at 598 (ch. 26).

${ }^{225}$ See, e.g., N. AUERBACH, supra note 21, at 70, 197-204 (linking references to Jane as a "witch" and "angel" to the "thoroughly demonic Bertha"); S. GiLBERT \& S. GUBAR, supra note 21, at 339 (analyzing Jane's confrontation with Bertha as an "encounter . . . with her own imprisoned 'hunger, rebellion, and rage" "); E. SHowalter, supra note 21 , at 118-22 (comparing Bertha's "animalism" to Jane's repressed "animal" nature).

${ }^{228}$ C. BRONTË, supra note 18 , at 610 (ch. 27).

227 See id. at $598-99$ (ch. 26).

228 Id. at 614 (ch. 27).

228 See id. at $672-77$ (ch. 33).

230 See id. at 623-37 (ch. 28). 
We are immediately alerted to the nature of her relationship with him, when, while she lies senseless from her ordeal, he discusses with his sisters her lack of beauty: "IIl or well, she would always be plain.' "231 Nonetheless, after some months of acquaintanceship, St. John determines to marry her. She will be his curate in his longawaited ambition to be a Christian missionary. In every way, his offer is the counterpoint to Rochester's. He does not love her. Instead of seeing her as beautiful, if only as an extension of himself, as Rochester did, he accepts her lack of sexual desirability. Unlike Rochester, he insists on marrying her; unlike her feeling for Rochester, she will do anything but marry him. Instead of being overmastered by passion, she feels herself overmastered by virtue. ${ }^{\mathbf{2 3 2}}$

The St. John episode plays a minor plot role, as well. Although she presented herself to the family with an alias, she doodles her real name on a drawing, and it emerges that the Rivers are her cousins and know that her uncle has died and left her his fortune. Yet, even though Jane is now an heiress and still longs for Rochester, she will not return to Thornfield. Economic equality, once grasped as some barrier to total submission, is not enough.

It is at this point that Jane, wealthy and well-connected, hears the sound she has been awaiting: Rochester's voice crying out in "pain and woe wildly, eerily, urgently." ascendancy. $M y$ powers were in play, and in force . . . Where there is energy to command well enough, obedience never fails." ${ }^{234}$ She returns to Thornfield. When she arrives, she finds what has set her powers into play. Bertha Mason had burst her bonds and set the Hall on fire. Attempting unsuccessfully to rescue her, Rochester was blinded and maimed. The Hall lay in ruins. ${ }^{235}$

She finds Rochester a "fettered wild beast," a "caged eagle," his "daring stride" halted, "a blind lameter," "a sightless block," "subjugat[ed]" to "a corporeal infirmity," living the life of a hermit in a damp, low, dark manor little better than a cave. ${ }^{238}$ "Reader, I married him."237 As well she might, since first she brought him down.

From the controlled universe of the novel, we can thus hear a woman's voice imagining an autonomous life. When we meet her, she is at her most helpless. In her helpless state, she describes her defects

\footnotetext{
${ }^{231}$ Id. at 638 (ch. 29).

232 See id. at 691-98 (ch. 34).

233 Id. at 706 (ch. 35).

234 Id. at 707.

298 See id. at 712-15 (ch. 36).

${ }^{238}$ Id. at $716,719-20,723$ (ch. 37).

237 Id. at 731 (ch. 38).
} 
and thus tells us what her quest for autonomy will involve: economic independence, human love, and social status. In this state, she tells us how the world feels to someone lacking autonomy-it is a blood-red death chamber from which she must escape. She tells us also how it makes her feel about herself. When the legitimacy of her aspirations is denied, she can envision liberation only in terms of self-destruction: starvation, flight, madness. ${ }^{238}$

She pursues love and work, the same avenues Freud immortalized fifty years later (but only for men). Love in patriarchal society, in which a woman's value extends only to her physical being, is perceived as attainable only by transforming herself into a shell, of value only for its grossest attribute-its appearance. When opportunities for meaningful work do not exist, work is perceived as attainable only as an extension of male charity. Lacking autonomy, women cannot experience human passion, including the physical. Confronted with this world, women turn into mad women or marble angels. In their madness, they seek to destroy the patriarchal society that imprisons them. Jane Eyre rose up, but only when Rochester was brought down.

When deciding if society has a right to impose its judgment in a matter so critical to female autonomy as the imposition of an unwanted pregnancy, Jane Eyre can tell us, as no political philosophy can, that we are proposing to do an act with great moral consequences to another human being. Of at least equal importance, Jane Eyre tells us that the history of our society's treatment of women is such that the decision to take that autonomy away must be approached with the greatest caution, lest we accept this deprivation simply because it reproduces a familiar status. Although Charlotte Brontë did not speak of suspect classifications and the values of ordered liberty, she did teach us, as Allan Bloom anticipated, "to see the delicate distinctions among men, among their deeds and their motives."

For feminist theorist Catharine MacKinnon, this female claim to equal autonomy so graphically portrayed in Brontë's fiction begins and

${ }^{238}$ Thus, with all the power of symbolic expression available to writers of fiction, Charlotte Brontë revealed the central flaw in Ely's position on gender discrimination. Ely argues that women, who can vote, are not even entitled to claim under his generous reading of equal protection. Let them "protect themselves" in the political process, Ely says. J. ELY, supra note 11, at 169 . If women could exercise such unfettered selfadvancement in the short time that has elapsed since Jane reviewed her self-destructive options, we have indeed "come a long way, baby." See Lyons, supra note 11, at 758-59 (criticizing Ely's argument for assuming that all participants in the political marketplace have similar competitive advantages and for failing to acknowledge that some participants, such as women, have been conditioned to be averse to competition, lack confidence in their ability to compete, and defer to the needs of others).

239 A. BLoom, supra note 1 , at 61. 
ends the abortion debate. Women are an underclass; as such they undertake "intercourse under conditions of gender inequality." law depriving them of control over the consequences of such intercourse is unconstitutional because it perpetuates a social complex of inequality based upon gender. ${ }^{241}$ We might indeed stop here.

At its present level of development, however, MacKinnon's insight on the abortion question is not entirely satisfying. First, because it rests on her underlying assertion that women have already lost their autonomy when they undertake "intercourse under conditions of gender inequality, ${ }^{\text {242 }}$ her theory lacks a certain universality. One can hypothesize a female in all ways free of the society MacKinnon and Charlotte Brontë describe-for example, some otherwise-autonomous woman whose birth control simply fails for technical reasons. Her claim to the freedom to choose to participate in the reproductive cycle must, in turn, relate back to some value more general than the liberation from the consequences of forced sex. Second, and particularly in the hypothetical situation described above, decisionmakers might say, Jane Eyre was right as to love and work, but as to pregnancy, only women can have children. Thus, as long as a woman has her autonomy in all other areas, reducing her autonomy in that area does not disparage her as compared to men; as between the sexes, we are treating different things differently, not the same things differently. I now turn to these contentions.

\section{B. Woman and Citizen: The Patriocracy of The Scarlet Letter}

To support the contention that the law is treating the same things differently, one may need to broaden the framework within which the equality inquiry is made. Kenneth Karst suggests that "equal protection" means "equal citizenship," which he defines as respected, participating membership in the community. ${ }^{243}$ Karst suggests that the problem with abortion regulation derives from, and must be compared to, acts depriving any individual of the "ability to make responsible choices in controlling one's own destiny, to be an active participant in society rather than an object." ${ }^{\text {244 }}$ Karst's theory does not rest on the fact this policy happens to be linked to pregnancy.

At the end of Jane Eyre, Charlotte Brontë solved the problem of

${ }^{210}$ MacKinnon, supra note 160 , at 95-96.

241 See generally id. at 93-97 (criticizing Roe: "Reproduction is sexual, men control sexuality, and the state supports the interest of men as a group.").

${ }^{242}$ Id. at 95-96.

${ }^{263}$ See Karst, supra note 15, at 4, 52-59.

244 Id. at 58. 
women in society by putting her newly reconciled equals in a cave in the woods, where they saw no one of social consequence. ${ }^{245}$ The primeval forests of the new world might similarly have liberated Europeans, offering freedom from patriarchal rigidities, freedom to recreate society in this vast and empty land. Many of the English settlements did involve some such reforming impulse; the prophetic approach to constitutional decisionmaking derives much of its force from its tie to this aspect of the past. ${ }^{248}$ In many ways, The Scarlet Letter retells the new world's failure to achieve an alternative to patriarchal society. This aspect bears most importantly on our inquiry.

When Hester Prynne emerges from her prison, she bears the interchangeable symbols of her fall: the Scarlet " $\mathrm{A}$ " "fantastically embroidered and illuminated upon her bosom," "247 and her infant daughter Pearl, "[a] being of great price." ${ }^{\text {"48 }}$ We know then that the story's impetus will be Hester's female sexuality, and that it will explore the meaning of a life so defined.

It is Hester's fate to be separated from her community, the "throng of bearded men in sad-colored garments and gray, steeplecrowned hats"240 who make up the Puritan patriarchy to which she has been exiled. She shrugs off the hand of her jailer and alone ascends the pillory. Her sexual availability coupled with her social helplessness threaten as well the Puritan women; they speculate uneasily that she may lead other "wives and daughters" to go astray. ${ }^{250}$

Hester is isolated even from the other guilty party. Puritan Boston is a small colony, yet the governors supposedly do not know his identity. Although both the governor and the chief minister of the colony attend Hester's pillory, each shows a reluctance to question her, passing the task along to her own minister, Arthur Dimmesdale. Dimmesdale is instantly recognizable as the only possible candidate for her partner in sin. He is handsome as Hester is beautiful, young as she is youthful, from a gentle background, as she is from fallen aristocrats. She stands high on the scaffold, and he stands in "high eminence in his profession" with his "high native gifts" and his "speech of an angel."251

245 See C. BRONTE, supra note 18, at 715-35 (chs. 37-38).

${ }^{245}$ See supra notes $42-45$ and accompanying text. One such settlement was founded by a woman-Ann Hutchinson, the first character we meet in The Scarlet Letter and whose story is a major subtext of the novel. See N. HAWTHORNE, supra note 19 , at 43 (ch. 1).

247 N. HawthorNe, supra note 19, at 47 (ch. 2).

248 Id. at 76 (ch. 6).

248 Id. at 42 (ch. 1) (emphasis added).

230 Id. at 46 (ch. 2).

${ }^{281}$ Id. at 58 (ch. 3). 
He begs her not to betray him. ${ }^{252}$

She will not. Unsullied, he rises to greater and greater political authority and moral stature within the community until his zenith as the preacher of the Election Day Sermon. ${ }^{253}$ We do not even know whether her accusation would have brought him down. After all, no test existed to prove his identity and, for all their severity in insisting that Hester identify with her adultery, the Puritan fathers never again ask Hester for her co-adulterer's name. When a man of science proposes studying the child for identification, the fathers fob him off with pious platitudes. ${ }^{254}$ Even when Dimmesdale ultimately decides to confess and shows his scarlet stigma, his "friends" see no marks on his chest and take his words to be a parable. ${ }^{255}$ Hester, of course, has no such choice.

Cut off from established society, Hester Prynne can survive only as the representative either of an antisocial nature or of an alternative society. Hawthorne toys with both; indeed for a long time it was cheap currency to read The Scarlet Letter as positing the positive law of Puritan morality against Hester's natural law of true passion, represented by the primeval forest and the sea. ${ }^{256}$ Not surprisingly, in more unbuttoned times, the conflict between romantic sexuality and Puritan morality being resolved, this understanding of the story drained it of most of its interest. ${ }^{237}$

Seen as a political tale, however, The Scarlet Letter remains both compelling and disturbing. It stands in direct opposition to the life of the noble savage, with which Brontë offers to resolve Jane Eyre. ${ }^{258}$ Both Hester and Arthur Dimmesdale repeatedly reject the option of a new frontier. She remains in the settlement even after being released from prison, and he suffers the pangs of mortal sin to maintain his

${ }^{252}$ Id. at 58-59. Reverend Dimmesdale tells Hester to confess his name, only if she feels "it to be for [her] soul's peace, and that [her] earthly punishment will thereby be made more effectual to salvation." Id. at 58 . He even tells her that it is her silence that "compel[s] him . . . to add hypocrisy to sin." Id. at 59.

${ }^{253}$ See id. at 202 (ch. 22).

254 See id. at 99 (ch. 8).

${ }^{288}$ Id. at 222 (ch. 24).

${ }^{258}$ See, e.g., F. Crews, The Sins of the Fathers: Hawthorne's Psychological Themes 270 (1966); L. Fiedler, Love and Death in the American Novel 492, 501-03 (1960); Carpenter, Puritans Preferred Blondes: The Heroines of Melville and Hawthorne, 9 NEw ENG. Q. 253, 271-72 (1936) ; Rahv, The Dark Lady of Salem, 8 PARTISAN REv. 362, 369 (1941).

${ }_{287}$ See E. HARDWICK, supra note 17, at 208 (arguing that a plot can no longer be constructed around a sexual encounter because sex is now considered an "episode"; "the old plot is dead" because "[y]ou cannot seduce anyone when innocence is not a value").

${ }^{288}$ See C. BronTË, supra note 18 , at $716-23$ (ch. 37). 
place in the community. When for a brief time he does contemplate flight, he experiences what the Greeks predicted would happen to an individual who absents himself from public life - he becomes an "idiot."288 Even the narrator (a quasi-authorial voice) tells us where he stands. Describing the "steeple-crowned" elders that open and close the book, he reminds us: "These primitive statesmen, therefore,-Bradstreet, Endicott, Dudley, Bellingham, and their compeers .... had fortitude and self-reliance, and, in time of difficulty or peril, stood up for the welfare of the state like a line of cliffs against a tempestuous tide."260

Escape being cut off, the struggle is for power in the society. In this, Hester's real battle is not with Dimmesdale, but with that representative of patriarchal society-the man whose property was violated-her husband, Roger Chillingworth. Old, wealthy, and learned, he, like Edward Rochester, tried to claim the innocent heroine for his sole possession. When his governance was defied, he became the very embodiment of the society's revenge, exacting at every turn a price even the Puritan fathers were unwilling to extract. Yet he recognizes that he overreached for her and seeks from her no further satisfaction for her infidelity. ${ }^{281}$ How, then, is he harmed? And why is the male rival the agent of his harm? Dimmesdale did not know Chillingworth. He owed him nothing of personal loyalty or friendship. Between Chillingworth and Dimmesdale, the violation is entirely political. Ghillingworth, representing the male ownership of women's sexuality, must prevail over Dimmesdale; ${ }^{262}$ yet while Dimmesdale lives, ${ }^{263}$ he may always run away with her. ${ }^{264}$

Hester cannot beat the patriarchy. Battling a society that defined women by their sexuality and compelled them to bear and bear alone the message of -sexuality and reproduction, Hester is lucky to be able to keep her rebellious thoughts to herself. "[S]tanding alone in the world . . she cast away the fragments of a broken chain. The world's law

259 See Webster's New International Dictionary of the ENGlish LaNGUAGE 1237 (2d ed. 1955) (English word "idiot" derives from the Greek "idiotes," meaning "a man not holding public office.").

${ }^{280}$ N. HAWTHORNE, supra note 19 , at 203-04 (ch. 22).

${ }^{261}$ See id. at 64-65 (ch. 4).

${ }^{282}$ See Karst, supra note 15 , at 46-59.

${ }^{263}$ The punishment for adultery was death for both parties. See THE BoOK of the General Lawes and Libertyes Concerning the InHabitants of the MASSAChUSETS 6 (1648); see also N. HAWTHORNE, supra note 19, at 55 (ch. 3). Hester enjoyed extraordinary mercy, probably because she didn't matter enough to be killed.

${ }^{264}$ Witness the lovers' short-lived agreement to flee. See N. HAwthornE, supra note 19 , at $172-73$ (ch. 18). 
was no law for her mind."265 Before we learn of her thoughts, we are warned:

[S] he might have come down to us in history, hand in hand with Ann Hutchinson, as the foundress of a religious sect. She might, in one of her phases, have been a prophetess. She might, and not improbably would, have suffered death from the stern tribunals of the period, for attempting to undermine the foundations of the Puritan establishment. ${ }^{268}$

What are these capital thoughts that, worse than the adultery, she, as a woman, could not conceal?

[W]ith reference to the whole race of womanhood[,] [w]as existence worth accepting, even to the happiest among them? ... As a first step, the whole system of society is to be torn down, and built up anew. Then, the very nature of the opposite sex, or its long hereditary habit, which has become like nature, is to be essentially modified, before woman can be allowed to assume what seems a fair and suitable position. Finally, ... . woman cannot take advantage of these preliminary reforms, until she herself shall have undergone a still mightier change; in which, perhaps, the ethereal essence, wherein she has her truest life, will be found to have evaporated. ${ }^{267}$

What is her truest essence? "Tenderness."288 What follows its evaporation? The "turn[] . . . from passion and feeling, to thought."269 Thus, women must be tethered to their sexuality, with all the implications so carefully laid out in The Scarlet Letter, lest they turn to thought-and revolution. Describing the female Messiah in his closing words, Hawthorne sounds a lot like Norman $\mathrm{Mailer}^{270}$ on what the feminists of his era really needed: "[L]ofty, pure, and beautiful; and wise, moreover, not through dusky grief, but the ethereal medium of joy; and showing how sacred love should make us happy, by the truest test of a life successful to such an end!'”271

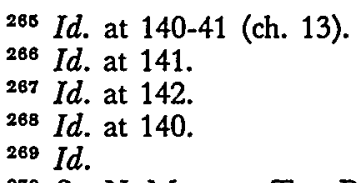

270 See N. Mailer, The Prisoner of Sex 168 (1971) (concluding that the feminist movement does serve a purpose because "[w]omen must have their rights to a life which would allow them to look for a mate. And there would be no free search until they were liberated. So let woman be what she would, and what she could.").

${ }^{271}$ N. HAWTHORNE, supra note 19, at 225 (ch. 24). 
I've titled this essay for Brontë, because Jane Eyre is the paradigmatic female claimant to equal human autonomy in the private sphere. If Jane Eyre cannot educate the reader to the immorality in the legally enforced deprivation of autonomy, then the more specific lesson of The Scarlet Letter will be lost. If the analysis on the prepolitical individual level is sound however, The Scarlet Letter graphically illustrates the political morality of creating-or maintaining-a female underclass.

Hester Prynne and Arthur Dimmesdale committed the same $\sin ^{272}$ In their world, as in ours, the act of accepting responsibility for the sin and the child who is its visible symbol is a decision of the utmost moral seriousness. He is allowed to make that decision. She is not. Therein lies the fundamental inequality, then and now. In Hawthorne's Boston, the moral autonomy to qualify for redemption was the definition of full humanity. Dimmesdale can and must struggle for it. Hester has it thrust upon her. The only redemptive act remaining to her is the toleration of pain.

The counterpart to moral autonomy in the theocracy of the novel may, in a secular republic, be called citizenship. As Karst has suggested, such autonomy involves, at a minimum, control over those aspects of one's earthly destiny critical to being a respected, participating member of society. ${ }^{273}$ The Scarlet Letter portrays the physical, emotional, social, economic, and psychological consequences of reproduction to women. By making Hester's sexuality determine her social fate, Hawthorne metaphorically makes the critical point: a society that denies women the freedom to control their role in the reproductive cycle strips them of the autonomy necessary to real citizenship. Their sexuality, enforced by law, determines their fate.

This point is the real meaning of Donald Regan's attempt to place the abortion issue into the context of the law of Good Samaritanism generally. After examining the prohibition of abortion as an issue in the law of Samaritanism, Regan concluded that an imposition of such a magnitude, based on such an attenuated connection, is totally inconsistent with the other obligations society imposes on its members. ${ }^{274}$ From this conclusion he draws the obvious equal protection argument, which

${ }^{272}$ Cf. MacKinnon, supra note 160 , at $94-95$ (questioning whether women submit voluntarily to sexual encounters). Although one's sense of injustice is greater if Hester was not only abandoned but also seduced, the assumption that she shared equally in the sin poses a harder and therefore more interesting moral problem.

${ }^{273}$ See Karst, supra note 15, at 58.

274 See Regan, supra note 40, at 1591-92. Regan credits the original thought to Judith Jarvis Thomson who first drew the analogy between a pregnant woman and one to whom another adult - say a concert violinist-becomes attached. See id. at 1576 n.4 (citing Thomson, A Defense of Abortion, 1 PhIL. \& PuB. Afr. 47, 62 (1971)). 
he reinforces with the fundamental nature of the rights to non-subordination and to freedom from physical invasion and with the suspect nature of the gender classification inevitably involved. ${ }^{275}$ Although Regan makes a deft argument, it really only buttresses the lesson of The Scarlet Letter: once the seriousness of the decision to bear or beget a child is recognized, excluding women from citizenship by denying them this freedom is wrong. ${ }^{278}$

In its rich symbolism, The Scarlet Letter illuminates as well the hard question whether, against all of these contrary indications, an upright state must still intervene because of a moral claim on behalf of the potential life. ${ }^{277}$ Is the preservation of the fetus sufficiently compelling to force pregnancy on an unwilling woman?

The product of Hester's pregnancy is the child Pearl. Although on the story's surface Hester gives birth to Pearl in prison, in a deeper sense Pearl is not born until she is acknowledged by her father. Throughout the book, she remains entirely isolated with Hester, a pearl in the oyster. When we first see her, she is but the outward manifestation of her mother's shame; a symbol, like the scarlet letter, reflecting her mother's mental and physical state in her pregnancy. ${ }^{278}$ Through this device, the novel enables us to examine the meaning of a fetus: an entity entirely within a woman's body.

What was Pearl? Despite unbroken contact, Hester cannot educate her, nor develop any emotional relationship with her. Pearl is repeatedly described as something extra-human: a "sprite," an "elf," a "little bird of scarlet plumage."279 The governors of the Puritan patriocracy do not wish to identify her in a family; leaving the mystery of her actual paternity as they find it, ${ }^{280}$ they allow Pearl "every good Christian man" as her father. ${ }^{281}$ Lacking worldly order, she encompasses not an individual development, but represents all children. ${ }^{282}$

Only when her father ascends the scaffold and takes her hand does

275 See Regan, supra note 40, at 1571.

${ }^{276}$ That society imposes no analogous coercion on any other group, of course, certainly bolsters the conclusion that this exclusion is invidious and discriminatory. See id. at 1591-92.

${ }^{277}$ As a technical legal matter, once the woman's right to decide is established as an element of equal citizenship within the fourteenth amendment, the treatment of the fetus properly falls on the opposite side of the balance-the state interest. Under Roe v. Wade, 410 U.S. 113 (1973), the state's interest in protecting the potential life does not tip that balance until the third trimester when the fetus becomes viable. See id. at 163.

278 See N. HAWTHORNE, supra note 19, at 77 (ch. 6).

279 Id. at $78,83,93$ (chs. $6 \& 8$ ).

${ }^{280}$ See id. at 112 (ch. 2).

${ }^{281}$ Id.

${ }^{282}$ See id. at 77 (ch. 6). 
she stir to life. ${ }^{283}$ Striving to be born, she repeatedly demands that he present her to society as his child, his responsibility, his sexuality. When he finally does so, "[a] spell [is] broken." 284

Thus the depiction of Pearl, as great art sometimes can, tells the story of the "other." "What are babies to men?" Gatharine MacKinnon asks. ${ }^{285}$ Until they are born (or, if the phrasing makes any difference, until, if born, society could claim them and raise them), they are not human. They are the prehuman expectancy of all humanity. They are not social beings. They cannot be educated. They cannot love or hate. They have no history of human attachments. Surely, The Scarlet Letter tells us that a just society cannot commandeer this woman in this inchoate interest.

\section{Society's Incubator: The Handmaid's Tale}

One argument remains. Margaret Atwood's dystopia, The Handmaid's Tale, centers on the premise-dear to scholars of the abortion problem ${ }^{288}$ - that the birthrate has fallen so low that society must conscript women to reproduce. ${ }^{28 z}$ Although current debate posits a declining population only to justify prohibiting abortion after conception, The Handmaid's Tale forces the reader to consider whether that interest could not also be used to prohibit contraception during the act and ultimately to compel the intercourse itself. This inquiry is not too farfetched. After all, Griswold v. Connecticut, ${ }^{288}$ which struck down state prohibition on contraception use, was the subject of searing academic criticism $^{289}$ that anticipated many of Ely's arguments against Roe $v$. Wade. ${ }^{280}$

In The Handmaid's Tale, male fundamentalists ("Commanders of the Faithful"), driven by a falling population, stage a violent coup and engineer a religious takeover of the United States, renamed "Gilead." Slowly but relentlessly, the commanders drive women into their places. First, women lose control over their money. ${ }^{291}$ Immediately thereafter

${ }^{283}$ See id. at 219 (ch. 23).

284 Id.

285 MacKinnon, supra note 160 , at 93 . We may ask, what are babies to anyone other than the mother?

${ }^{288}$ See Regan, supra note 40, at 1607-09.

287 The reasons for the decline are many; toxic pollutants, venereal disease, women's decisions to sterilize themselves. See M. ATwood, supra note 20, at 385-86.

288381 U.S. 479 (1965).

289 See Bork, Neutral Principles, supra note 5, at 7-9.

280 See Ely, Wages, supra note 34, at 920.

291 In Atwood's Gilead, the Married Woman's Property Acts take the rather simple form of closing women's access to computerized bank accounts. See M. ATWOOD, supra note 20 , at 231 (ch. 28). 
they are discharged from their jobs.

Deprived of their power, women slowly lose their freedom. The governors do not impose their new regime without opposition. "There were marches, of course." ${ }^{\text {292 }}$ After the initial coup, however, the governors turn increasingly to enforced terror. Starting with the male abortionists ("gender traitors"), the governors begin systematically butchering people who pursued sexual lives unconventional by fundamentalist standards. The resistance slowly dies out. Single women beyond childbearing and troublemakers ("unwomen") are shipped to the colonies, to clean up toxic waste, until their inevitable demises. Fertile women who are not first wives become Handmaids, and it is the Handmaid's tale we hear.

$\mathrm{Sh}^{293}$ is accorded no social value save childbearing. For each of three two-year terms she is assigned to a Commander of the Faithful, with whom she has intercourse once monthly, when she is fertile. She may not smoke or drink, and she is permitted to eat only healthy food. She may not read or write; indeed, she has no occupation but occasional food shopping and practicing her natural childbirth exercises. She becomes like all Handmaids: "two-legged wombs, that's all: sacred vessels, ambulatory chalices." ${ }^{204}$ If she conceives, after her third term she may retire; if she has not conceived by then, she will become an unwoman and be sent to the colonies. When we meet her, she is at her third post.

What does it feel like, when one's only value is conception? She longs for power. Confined in her red prescription muu-muu, her peripheral vision cut off by a nun-like wimple, she contrives to exchange a glance with a virginal young guard. This slight defiance provides a rare opportunity to control her sexuality:

I move my hips a little, feeling the full red skirt sway around me. It's like thumbing your nose from behind a fence or teasing a dog with a bone held out of reach, and I'm ashamed of myself for doing it, because none of this is the fault of these men, they're too young.

Then I find I'm not ashamed after all. I enjoy the power, power of a dog bone, passive but there. ${ }^{295}$

${ }^{202} \mathrm{Id}$. at 232 (ch. 28).

293 "She" has no personal identifier. Handmaids are stripped of their original name and issued a temporary patronymic composed of the possessive preposition "of" and the first name of the Commander to whom they are assigned. Id. at 387 (historical notes). During the tale, at her third post, "She" is called "Offred."

294 Id. at 176 (ch. 23).

${ }^{298} \mathrm{Id}$. at 30 (ch. 4). 
She eyes the kitchen knives and the garden shears. She cadges a single match and hides it for months against an event.

She remembers her freedom of choice: ${ }^{296}$ to hang out, to have a name, to get an ice cream cone:

There used to be an ice cream store, somewhere in this block. I can't remember the name .... You could get double scoops, and if you wanted they would put chocolate sprinkles on the top. These had the name of a man. Johnnies? Jackies? I can't remember.

We would go there when she was little, and I'd hold her up so she could see through the glass side of the counter, where the vats of ice cream were on display, colored so delicately, pale orange, pale green, pale pink, and I'd read the names to her so she could choose. She wouldn't choose by the name, though, but by the color. Her dresses and overalls were those colors too. Ice cream pastels.

Jimmies, that was the name. ${ }^{297}$

More than any freedom, she remembers her freedom to decide and to have a child: "The little girl who is now dead sits in the back seat, with her two best dolls, her stuffed rabbit, mangy with age and love. I know all the details. They are sentimental details but I can't help that."288 She also remembers the freedom to choose her own lover:

I want Luke here so badly. I want to be held and told my name. I want to be valued, in ways that I am not; I want to be more than valuable. I repeat my former name, remind myself of what I once could do, how others saw me. ${ }^{299}$

To subdue her to Handmaid status, the Commanders had to strip her of her freedom, her associations, her identity; to reduce her to her body; but then she could only occupy it, not, as she once could, be its master. A mere tenant in her own form, a "two-legged womb" deprived even of Hester Prynne's sexuality, she still fights. Flirting with the guard and, more dangerously, embarking on an affair with the Commander's chauffeur ("I did not do it for him, but for myself en-

200 Before she became a Handmaid, when there was still some space left before the regime closed in, she did not yield. She retreated. As the regime closed in, she, her husband, and her daughter tried unsuccessfully to escape to Canada. Id. at 290-91 (ch. 35).
297 Id. at 213 (ch. 27).
${ }^{208} \mathrm{Id}$. at 108 (ch. 14).
${ }^{289}$ Id. at $125-26$ (ch. 17). 
tirely."), ${ }^{300}$ she does not fully "resign" her body to them until the tale's end-when she thinks the secret police van is coming for her. ${ }^{301}$

Her decision to seek the freedom of sex with the chauffeur instead of seeking freedom itself might be read as a parable of woman adopting the values of her oppressors. That reading would betray the most consistent theme of the book-the Handmaid's refusal to give up the possibility of choice, unless her refusal means certain and immediate death. She cannot refuse the Commander. But she can, with a reduced risk of her demise, imitate the remembered world of choice by seeking out the chauffeur.

The theme of the lost power of choice pervades even the ambiguous subtext of the novel: that the repression resulted from too much freedom and that it has the benefit of protecting women from freedom's excesses. She remembers a different repression before the siege:

I never ran at night; and in the daytime, only beside well-frequented roads.

Women were not protected then.

I remember the rules, rules that were never spelled out but that every woman knew: Don't open your door to a stranger, even if he says he is the police. Make him slide his ID under the door. Don't stop on the road to help a motorist pretending to be in trouble. Keep the locks on and keep going. If anyone whistles, don't turn to look. Don't go into a laundromat, by yourself, at night. ${ }^{302}$

Undaunted, the Handmaid has a different memory of laundromats: "I think about laundromats. What I wore to them: shorts, jeans, jogging pants. What I put into them: my own clothes, my own soap, my own money, money I had earned myself." ${ }^{303}$ Her Commander tries in vain to justify the new order as better for women:

[I]f they did marry, they could be left with a kid, two kids, the husband might just get fed up and take off, disappear, they'd have to go on welfare .... Money was the only measure of worth, for everyone, they got no respect as mothers. No wonder they were giving up on the whole business. This

${ }^{300}$ Id. at 344 (ch. 41).

301 The story's end implies that the Handmaid's lover saves her. See id. at 376 (ch. 46). Other than her indomitably free will, she's a rather ordinary woman, so she may meet this rather banal romantic end. Since her act of seeking him was a reclamation of herself, that he should be the first link in the "Underground Femaleroad" to Canada is somewhat fitting.

${ }^{302}$ Id. at $32-33$ (ch. 5).

${ }^{303}$ Id. at 33 (ch. 5). 
way they're protected, they can fulfill their biological destinies in peace. With full support and encouragement. ${ }^{304}$

In response, the Handmaid remembers choosing her own mate. ${ }^{305}$ From her viewpoint, men exposed her to the evils she describes in the world she knew before; they repress her now. Although she would obviously prefer the prior excesses of freedom to the current repression, the evil was her loss of choice both times.

Only Mary McGarthy wasn't scared by The Handmaid's Tale. ${ }^{308}$ If society's interest in potential life were enough to compel women to bear children after one sexual encounter, by prohibiting abortion, why couldn't society compel the encounter itself? The physical and psychological infringement of a woman's liberty in childbearing, to say nothing of child rearing, is tremendous; if society can compel incubation, is one sexual encounter a month much of an additional burden? After all, the Constitution doesn't say "nonprocreation" anywhere.

Of course, it can't happen here. Our "tradition of ordered liberty" would forbid such a thing. Why, Margaret Atwood had to kill off the President and Congress and declare a state of emergency before she could establish her patriarchy. As Ely points out, however, one can find tradition for any position. ${ }^{30 z}$ We were a slave nation for eighty years; men freely enjoyed sexual access to their slaves. Even now, it is not at all clear that a man commits a crime when he rapes his wife. ${ }^{308}$ Maybe Atwood had no need to hypothesize abolishing the Republic. Maybe just a state-by-state rule compelling fertile women to submit to any man once a month would do. Women would be left otherwise free to live their lives as they please. Unless, of course, they become pregnant.

But think of enforcing such a rule. Look at the beatings, the executions, the elaborate system of spies required to maintain Gilead. Surely, even a less Draconic rule could be struck down on grounds such as those Ely invoked ${ }^{309}$ to justify striking the ban on contraception in Griswold: it would violate the fourth amendment. Think also, however,

304 Id. at 284 (ch. 34).

sos Id.

${ }^{306}$ See McCarthy, Breeders, Wives and Unwomen, N. Y. Times, Feb. 9, 1986, $\S 7$ (Book Review), at 1,30 ("[A] future that has no language invented for it lacks personality. That must be why, collectively, it is powerless to scare.").

${ }^{\text {so7 }}$ See J. ELY, supra note 11, at 60 ("The first [problem] is that people have come to understand that 'tradition' can be invoked in support of almost any cause."). ${ }^{\text {sos }}$ See Note, The Marital Rape Exception, 52 N.Y.U. L. REv. 306, 318-19 (1977); see also People v. Kubasiak, 98 Mich. App. 529, 531-35, 296 N.W.2d 298, 301 (1980) (an actor does not commit rape if the victim is his spouse unless the parties are living apart and one of them has filed for separate maintenance or divorce). See generally 75 C.J.S. Rape $\S 6$ (Supp. 1988).

${ }_{309}$ See Ely, Wages, supra note 34, at 930. 
what it would take to go back to the era before Roe v. Wade; if all state rules were consistent and forbade all abortions, think about the black market that would inevitably return. What would it take to enforce the legislation one might expect to follow the overruling of Roe v. Wade?

One last shot from those who are not scared: Nobody is talking about Gilead. Margaret Atwood's dystopia has served its salutary function. Our society is not that intensely interested in potential life. Laws making abortion criminal would apply only after a woman has voluntarily put herself at risk by her own sexual activity. And don't start calling us the Puritan fathers; we're sorry we have to punish women for their sexual activity, especially if they were raped or juvenile victims of incest. ${ }^{310}$ It's just that we can't figure out how to distinguish two cells in a womb from a concert violinist. ${ }^{311}$ Women and their doctors, we know, won't easily go back to 1972; but rather than confront a failure of legal reasoning, we stand ready to fill our prisons with them. And you say no one is talking about Gilead? It is not surprising that The Handmaid's Tale, a dystopia and therefore at its first level a political commentary, would point most directly at the political issues in the abortion debate that spurred this inquiry. By forcing a confrontation with the ultimate consequence of conscripting unwilling women to the reproductive function, the argument in favor of regulating abortion is ultimately reduced to its core: we feel inadequate to the task of dealing with the ambiguous being that is the creature from egg to newborn. We will take drastic measures rather than succumb to an imperfect rule. This preference seems, by the way, to be the direction of Justice O'Connor's dissents. ${ }^{312}$

This absolutism certainly embraces with a vengeance David Hume's attitude, implicit in his attack on pragmatic induction, that "no

s10 Punishing women for seeking abortions (should Roe be overturned) became an issue in the first debate of the 1988 presidential race. Vice President George Bush supported the banning of abortions (except in limited circumstances) but could not articulate how or if the state would be allowed to punish women for seeking abortions. See N.Y. Times, Sept. 26,1988, at A1, col. 5. The next day his campaign stated that he would only support punishing doctors for performing abortions. See id.; $c f$. Harris v. McRae, 448 U.S. 297, 302-03 (1980) (describing previous versions of the Hyde Amendment that would have prohibited Medicaid funding for abortions even when the woman had been the victim of rape or incest); S.J. Res. 291, 99th Cong., 2d Sess. (1986) (right-to-life constitutional amendment).

s11 See City of Akron v. Akron Center for Reproductive Health, Inc., 462 U.S. 416, 458-61 (1983) (O'Connor, J., dissenting) (discussing the arbitrariness inherent in the determination of viability and thus in the determination under Roe of the point at which the state's interest in potential life becomes compelling. "The Roe framework, then, is clearly on a collision course with itself." Id. at 458).

312 Id. 
rule but the best will do." ${ }^{\text {s1s }}$ By contrast, the literature is replete, as are the reporters, with rules that are hard to live with given the hard cases that generate law review articles. ${ }^{314}$ That is rarely reason to refuse to draw lines. Indeed, to cite one example, society easily draws as difficult a line whenever it distinguishes between minors and fully responsible adults. ${ }^{315}$ With regard to abortion, a host of less drastic means exist. Against a background of our enhanced understanding of the fetus as becoming fully human only when people other than the pregnant woman can claim it, ${ }^{\mathbf{3 1 6}}$ the Court's original choice of viability, when society could support the fetus' life, has an ongoing moral appeal. ${ }^{\mathbf{3 1 7}}$ Donald Regan proffers another means. He supports drawing a line so as to give a woman ample opportunity to exercise her rights, but then charging her with waiver. ${ }^{\mathbf{3 1 8}}$ His formulation has the attraction of respecting the autonomy value discussed above. A good argument also exists that a woman should have the option to choose not to carry the pregnancy to term even after viability, by seeking a post-viability abortion to be performed in a manner enabling the community to exercise its right to preserve the life on its own. Each of these suggestions rests on the same ground, and that is the intuition brought to light by the literature: the female half of the human species has a claim to full citizenship in society, and that claim is too important to be subordinated to a craving for legislative perfection.

31s Hegland, supra note 97 , at 1217 n.35, traces to Hume the "fatal error of deconstruction . . . concluding, from the fact that there is never a perfect match between rule and result, that there is no relationship between them." Hegland cites D. StOve, Popper and AfTer: Four Modern IrRationalists 83 (1982) who finds this wrong turn implicit in D. HUME, AN ENQUIRY CoNCERNING HuMaN UंNDERSTANDING 25-55 (3d ed. 1983).

314 See Hegland, supra note 97, at 1212-14.

315 For example, criminal law treats minors and adults differently. By common law and statute, states generally treat children under sixteen or seventeen years of age as incapable of committing a crime. The courts treat minors' offenses as juvenile delinquency-a civil rather than criminal matter, calling for treatment rather than punishment. W. LaFave \& A. SCOTT, CRiminal Law, § 1.7 at 37-38 (2d ed. 1986); see also Thompson v. Oklahoma, 108 S.Ct. 2687, 2687 (1988) (eighth and fourteenth amendments prohibit the imposition of capital punishment for crimes committed before the age of 16); Kent v. United States, 383 U.S. 541, 554 (1966) (law provides "rehabilitation for the child and protection for society, not to fix criminal responsibility, guilt, and punishment").

The Court also distinguishes between the first amendment rights of a child and an adult. See Hazelwood School District v. Kuhlmeier, 108 S. Ct. 562, 567 (1988) (upholding prior restraint of public high school newspaper by principal).

${ }^{316}$ See supra notes $279-85$ and accompanying text.

317 See Rhoden, supra note 14, at 669 (the dichotomy between late and early abortions is the closest society has come to a consensus on the morality of abortion).

318 See Regan, supra note 40, at 1643. 


\section{CONCLUSION}

Once in a while literature expresses an insight that saves a lot of space. Whenever I read the conclusion in a law review article, I think of the story about Rabbi Hillel. In the story, an insolent heathen comes to the great Rabbi and demands that he teach him the entire Mosaic canon while his interlocutor stands on one foot. Rabbi Hillel replies, "What is hateful to you, do not do to your neighbor: that is the whole Torah, while the rest is the commentary thereof; go and learn it."s18

In the spirit of Rabbi Hillel, "Books do furnish a room."320 All the rest is commentary; go and learn it. 
